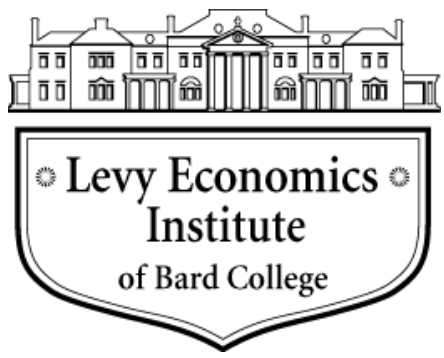

Working Paper No. 965

\title{
First Palestinian Intifada and Intergenerational Transmission of Human Capital
}

\author{
by \\ Sameh Hallaq* \\ Levy Economics Institute of Bard College \\ and \\ Al-Quds Bard College
}

July 2020

\begin{abstract}
* The analysis presented in this paper is part of the project "Determinants of Cognitive Development in Deprived Environments: Evidence from the West Bank" funded by the German Research Foundation (DFG) under grant number JU 2769/2. We are grateful to the Palestinian Ministry of Education, test administrators, and the students who participated in our study for their time and effort.

The Levy Economics Institute Working Paper Collection presents research in progress by Levy Institute scholars and conference participants. The purpose of the series is to disseminate ideas to and elicit comments from academics and professionals.
\end{abstract}

Levy Economics Institute of Bard College, founded in 1986, is a nonprofit, nonpartisan, independently funded research organization devoted to public service. Through scholarship and economic research it generates viable, effective public policy responses to important economic problems that profoundly affect the quality of life in the United States and abroad.

\author{
Levy Economics Institute \\ P.O. Box 5000 \\ Annandale-on-Hudson, NY 12504-5000 \\ http://www.levyinstitute.org
}

Copyright (C) Levy Economics Institute 2020 All rights reserved

ISSN 1547-366X 


\begin{abstract}
This paper attempts to estimate the intergenerational transmission of human capital in Palestine. The main question is whether formal parental education improves their offspring's cognitive skills and school achievements. I use the instrumental variable (IV) method in the estimations to overcome the potential endogeneity of parental education. The main source of variation in parental educational attainment is parents' exposure to the First Palestinian Intifada (1988-93) during their middle- and high school ages. During the First Palestinian Intifada, many school days were lost due to frequent school closures and other restrictions. Furthermore, many young people preferred to search for low-skill employment in Israel, since it provided them with better wages than the local labor market and hardly required any level of educational attainment. This study employs two outcomes, namely the standardized cognitive test scores and school achievements during the academic year 2012/13 for students between grade 5 and grade 9 in West Bank schools. Overall, the results support the hypothesis of a human capital spillover but more so for girls than for boys, where the IV results are often insignificant because of their large standard errors.
\end{abstract}

KEYWORDS: Intergenerational Mobility; First Intifada

JEL CLASSIFICATIONS: I20; J62 


\section{INTRODUCTION}

Investment in education in both the home and at school from an early stage shapes human capital and contributes to sustainable economic development. Heckman (2006) cited the great advantage of early intervention in the life cycle, since children's cognitive and noncognitive abilities develop through interaction with their parents and the surrounding environment. Economists have pointed to the consequences of early childhood circumstances and later-life outcomes (Currie 2001; Heckman, Pinto, and Savelyev 2013; Jürges 2013). Furthermore, they have highlighted the association between inequality in the distribution of both wealth and income and inequality in education, which has lasting effects beyond the generation that experiences it (Benabou 1994; Black, Devereux, and Salvanes 2005). Environmental factors have a significant role in determining students' school achievements and cognitive abilities at different learning stages. One of these factors is the child's socioeconomic status, which is profoundly affected by the parents' level of education. Well-educated parents can provide their children with a better learning environment, and many works in the literature have documented the importance of the intergenerational return to human capital (Anger and Heineck 2010; Bauer and Riphahn 2013; Black, Devereux, and Salvanes 2005; Chevalier 2004). Ideally, better-educated parents may increase their skills or knowledge relevant to the well-being and capabilities of a child. Researchers have suggested that parenting interventions may be more effective than health interventions in improving cognitive outcomes (Grantham-McGregor et al. 1997).

With regard to policy implications, it is important to know the long-run impact of investing in human capital. Economists have recognized the accumulation of human capital as a key determinant of economic growth (Van Leeuwen and Foldvari 2008). The importance of school education lies in the fact that the children of today will become the adult citizens of tomorrow. The economic growth and future of society are highly dependent on the quality of the present education. Moreover, governments spend a significant portion of their budget on education ${ }^{1}$; understanding the benefits of this spending can reduce the degree of inequality in the opportunity for education. Attention to such inequality will grow if there is evidence of a causal relationship

\footnotetext{
${ }^{1}$ For example, the education sector represents 18 percent of the Palestinian National Authority's public expenditures (MoFP 2016).
} 
between the educational attainment of parents and that of their offspring. At the national level (in particular, for the newly established state of Palestine) education plays a crucial role in securing economic and social progress in addition to improving income.

Parents have an important influence on their children's outcomes. On average, better-educated parents have better-educated children (Ermisch and Pronzato 2010). Parents transmit some abilities genetically or, on further examination, this may also partly reflect human capital spillovers from parent to child, since education may change the way in which parents interact with their children (Lee, Roys, and Seshadri 2015). Undermining a causal interpretation of the intergenerational correlation are aspects of the family environment that facilitate the acquisition of cognitive skills during childhood, which may also correlate with parents' education. A growing body of recent empirical studies have attempted to investigate the causal relationship between parents' and children's education. Economists have suggested three identification strategies to address the endogeneity problem caused by omitted variables: parents of twins (Behrman and Rosenzweig 2005); adopted children (Plug 2004); and instrumental variables (IV) (Black, Devereux, and Salvanes 2005; Chevalier 2004; Oreopoulos, Page, and Stevens 2006; Stella 2013). In this study, I employ the IV approach by identifying parents' exposure to the First Palestinian Intifada (1988-93) at the preparatory and high school ages ${ }^{2}$ to create an exogenous variation in their educational attainment. The political conflict during that period affected the ability of today's parents to attend schools without directly affecting their children. Losing school days during a political conflict causes severe damage to human capital, since this loss can translate into significant losses in lifetime earnings. Those Palestinian adolescents who were affected by conflict during the First Intifada are now parents, and their children represent the larger part of the human capital of their country. ${ }^{3}$

This study contributes to two distinct strands of the literature. First, it contributes to the literature that discusses the intergenerational transmission of human capital in developing countries. Most of the literature addressing human capital spillovers has focused on developed countries, while

\footnotetext{
${ }^{2}$ Before the establishment of the Palestinian Ministry of Education in 1994, grades were classified into three categories: elementary, grades 1-6; preparatory, grades 7-9; and secondary, grades 10-12. UNRWA schools provide education until the end of the preparatory stage (grade 9) (MoEHE 2016b; UNRWA 2014).

${ }^{3}$ At the end of 2013, 39.9 percent of the Palestinian population was under 15 years of age (PCBS 2014). Moreover, children in primary school accounted for 20 percent of the total human capital in the country (MoEHE 2015).
} 
the literature addressing developing countries has tended to focus on child outcomes, such as health, mortality, and well-being, rather than educational attainment. Second, it contributes to the body of literature discussing the long-term impact of the Israeli-Palestinian conflict on schooling and quality of education. To the best of my knowledge, this is the first study to take the First Intifada as an IV to create variation in parents' educational attainment. The paper also considers how political instability may give rise to distinct impacts on the educational outcomes of males and females, respectively. Therefore, the paper aims to discuss the varying roles played by mothers and fathers in the transmission of knowledge to their offspring.

The primary outcomes in this study are the test scores of survey data from approximately 4,000 students in grades 5-9 in West Bank schools. These data were collected by a cooperative research project funded by the German Research Foundation (DFG). The rich dataset provides information on educational attainment for two family generations. The data allow me to control for a large set of observed demographic and socioeconomic family background covariates that might affect a child's cognitive outcomes. I also control for the school fixed effect, which captures a range of unobserved differences across schools and covers other location-specific, unobserved determinants of students' abilities. The comprehensive breadth of the data enables me to formulate relevant policy recommendations within the Palestinian context.

The main results suggest that one more year of maternal education correlates with a 1.14 percentage point increase in a child's cognitive test scores. Focusing on female and male students' results separately, the study demonstrates a causal relationship between the schooling of both parents and that of their daughters. The magnitude of the estimated effect is large: an additional year of parental education raises girls' cognitive scores by 2 percentage points. Employing the school achievements for the 2012/13 academic year as a secondary outcome supports the positive educational spillover between both parents and their daughters. Unlike the primary outcome, the school performance results suggest a causal relation only between paternal schooling and offspring. The findings are robust to a number of specification tests.

The remainder of the paper is structured as follows. The second section discusses the background of the First Palestinian Intifada and its impact on education. Section 3 reviews the literature related to the intergenerational transmission of human capital and the effect of the ongoing 
Israeli-Palestinian conflict on education. Section 4 describes the data used in this study. In section 5, I present the empirical specification and the identification strategy. The ordinary least squares (OLS) and IV results are reported in section 6; section 7 provides robustness checks, while the discussion and concluding remarks are presented in section 8.

\section{BACKGROUND}

The Palestinian education system faced several challenges over the periods during which it was controlled by different authorities until 1994, when the Palestinian Ministry of Education (MoEHE) was established and became responsible for all educational processes in the Palestinian territories (i.e., the West Bank, East Jerusalem, and the Gaza Strip) (UNESCO 2011). Before then, and mainly between 1988 and 1993, all Palestinian territories were subject to different types of political violence due to the first Palestinian uprising (Intifada). During these years, the educational system in Palestine suffered severely from various Israeli actions against schools and universities.

The First Palestinian Intifada was an uprising against the Israeli occupation of the Palestinian Territories, which lasted from December 1987 until 1993 with the signing of the Oslo Accords. According to B'Tselem (2017), the first Intifada claimed the life of more than 1,000 Palestinians. $^{4}$

The events of the First Palestinian Intifada imposed several restrictions on adolescents' schooling. At that time, young people were hindered from obtaining their right to an education at various stages. Many factors led to the decline in the quality of education. One reason was the loss of school time during the Intifada resulting from frequent school closures, curfews, and other measures (UNESCO 1995). Table 2 shows an example of the destruction of the learning process during that period.

\footnotetext{
${ }^{4}$ During the First Palestinian Intifada, a large number of victims were children, 2,532 persons had their houses razed, and between 57,000 and 120,000 were arrested (López-Ibor et al. 2005).
} 
Table 2: Maximum Number of Days Schools Were Open, 1988-89

\begin{tabular}{lrr}
\hline Level & $\begin{array}{c}\text { Total no. of } \\
\text { open } \\
\text { days/year }\end{array}$ & $\begin{array}{c}\text { Percentage of } \\
\text { school days }\end{array}$ \\
\hline Elementary (grades 1-6) & 135 & 64 \\
\hline Preparatory (grade 7-9) & 115 & 55 \\
\hline Grades 10-11 & 85 & 40 \\
\hline Grade 12 & 120 & 57 \\
\hline
\end{tabular}

Source: Assaf (1997)

Note: Total number of school days per year: $205-210$

The learning environment and access to education suffered during the First Intifada. As a result of the lack of financial resources for maintenance or construction, schools in the West Bank were set up in rented buildings that were not constructed for this purpose. Schools operated on double or triple shifts, and classes were overcrowded (UNESCO 1995).

The Israeli Civil Administration and the Israeli army considered the universities' administrations to be directly responsible for the conduct of students and hence ordered the immediate closure of all Palestinian campuses. ${ }^{5}$ As a result, several Palestinian higher educational institutions were closed (Barghouti 2005). ${ }^{6}$ Figure 1 represents the number of students enrolled in West Bank universities before, during, and after the First Intifada.

The First Palestinian Intifada was characterized by a high level of youth participation and activism (Ghanem 2012). Because students played a vital role in the daily Intifada activities, their time and attention were directed away from education. Instead, they were exposed to different types of violence and were affected physically, socially, and psychologically (Barber 1997; Qouta, Punamäki, and Sarraj 1995; Tessler 2009).

\footnotetext{
${ }^{5}$ The universities remained closed until the autumn of 1991, with the exception of Birziet University, which remained closed until April 29, 1992 (Robinson 1997, 106).

${ }^{6}$ On February 2, 1988, Israeli radio announced that the Israeli army had ordered all 1,194 schools in the West Bank to close until further notice. In addition, six universities, thirteen colleges, and five government training schools were officially ordered to close (ARIJ 2007).
} 
Figure 1: Admission to Universities before and after the First Intifada (1989-93)

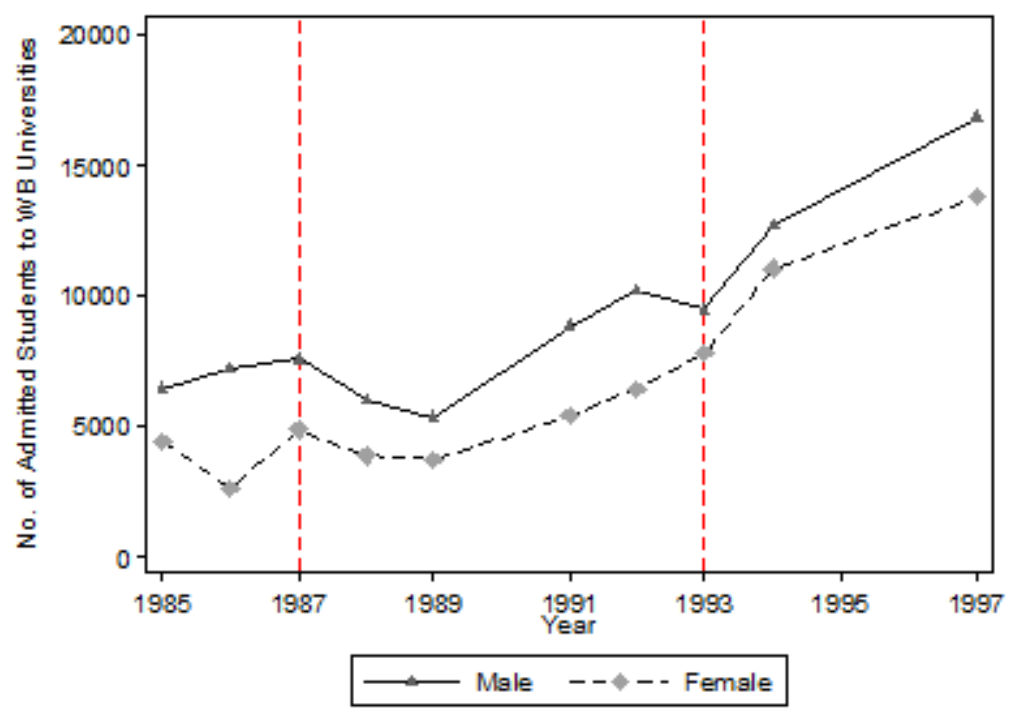

Source: Own calculation based on MoEHE (2016a) data.

School students were also less likely to complete their education due to economic factors. For decades, many young Palestinians searched for low-skilled jobs in the Israeli labor market, for example in construction and agriculture, since the Israeli market provided better daily wages than the local market. The salaries in the West Bank still increased regularly until 1988, when the First Intifada began, and wages decreased dramatically due to the curfews and strikes that prevented access to the Israeli labor market (Elkhafif and Daoud 2005). Additionally, during that period, there was less incentive to return to schooling in the Palestinian territories due to the increase in the number of Palestinian college and university graduates (Angrist 1995).

Despite the significant obstacles to formal education mentioned above, the motivation for learning increased during the First Intifada (Nasser, Berlin, and Wong 2011). Teachers and students managed to resume the educational process despite the damage caused by the closures. During the first two years of the Intifada (before the Israeli decision to reopen the schools and universities under pressure applied by the European Parliament), Palestinian society adopted alternative modes of education as a reaction to the closure of schools and universities. The following actions were key aspects of this alternative education: 1) universities set up offcampus classes; 2) universities set up popular or neighborhood schools in which teachers taught students within a geographic area; and 3) private and United Nations Relief and Works Agency (UNRWA) schools distributed special educational materials for remote education, for example 
learning objective assignments, self-evaluation tests, and graded exercises (Mahshi and Bush 1989).

\section{CONCEPTUAL FRAMEWORK AND RELATED LITERATURE}

Researchers have suggested that children's cognitive abilities have a significant impact on their future outcomes, such as earnings. These abilities may affect children directly as part of the individual overall human capital or indirectly through educational attainment if innate abilities determine schooling outcomes (Anger and Heineck 2010). Recently, a growing body of knowledge has suggested that low levels of cognitive development in early childhood have longterm adverse consequences for adult well-being (Paxson and Schady 2007). Further, other factors, such as the level of nonschool home activities and the quality of education, can be important inputs into human capital production (Glick and Sahn 2009).

There are two main channels for the transmission of cognitive skills between generations: the inheritance of genes ("nature") and the productivity effect of parental education ("causal") (Anger and Heineck 2010). To understand whether formal parental education improves children's cognitive abilities and school performance, researchers have suggested three possible channels for the correlation in education between generations: financial constraints, causal, and nature. Less-educated parents have a greater probability of facing financial concern than welleducated parents and this constraint will prevent their children from realizing their schooling potential (Becker and Tomes 1994). ${ }^{7}$ A parents' decision to invest in his or her child's education might be affected by their own observable and unobservable characteristics. Some of these features may be correlated with parenting skills, while others are genetically transmitted from parents to children, thus generating a correlation between parents' and offspring's cognitive abilities. To identify the causal relation of parents' education on their offspring, economists have relied on three identifying strategies: parents of twins, adopted children, and IVs. The first two strategies do not eliminate the nongenetic endogeneity that stems from unobservable

\footnotetext{
${ }^{7}$ Even when education is free, parents from higher socioeconomic backgrounds may send their children to wellresourced schools that provide a better education.
} 
characteristics in the educational choices, which are also correlated with parenting skills (Chevalier 2004). The related literature has differed in discussing the causal relationship between parents and their offspring's educational outcome based on these three strategies.

Chevalier (2004) used the change in the minimum age of school leaving that took place in the 1970s in Britain as a way of measuring the exogenous effect on parents' educational choice, at least for those wishing to drop out of school at the first opportunity. The law provided some parents with an extra year of education compared with parents born just before the reform. He found that mothers' education has a larger positive impact on that of their offspring but that fathers' education has no significant impact. Further, he pointed out that the intergenerational link in education is causal when focusing on natural parents only, while stepparents have no or a negative impact on children's education. ${ }^{8}$ Plug (2004) employed data on adopted children to investigate whether the intergenerational transmission of human capital is due to the causal relationship or other unobserved variables. The results demonstrated a positive effect of fathers' education on children's education but no significant effect for mothers. The maternal influence vanishes with innate genetic abilities and if assortative mating is taken into account. However, the results had two limitations: the sample size was small and children were not randomly placed with adoptive parents.

Björklund, Lindahl, and Plug (2006) estimated the intergenerational mobility in income and parents' education using data on adoptees born in Sweden and their biological and adoptive parents. They found that prebirth factors (e.g., genetic and parental education) and postbirth factors (e.g., long-term earnings) for both adoptive and biological parents contribute to intergenerational earnings and education transmission. In addition, they provided evidence that the biological mothers' coefficient in the intergenerational transmission coefficients was slightly larger than that of biological fathers.

Over the last decades, a growing body of literature has used the IV identification strategy to remove potential endogeneity from the estimated education spillover coefficient. Studies have taken advantage of real or "natural" experiments that produce exogenous variation in family and

\footnotetext{
${ }^{8}$ The estimations for stepparents in Chevalier's (2004) study are rather imprecise due to the small sample size.
} 
contextual variables of interest (Duncan, Magnuson, and Ludwig 2004). Black, Devereux, and Salvanes (2005) relied on the change in implementing the reform of the education system in Norway across different municipalities in 1960 to create an exogenous variation in parents' education. As a result, the IV estimations were consistently lower than the OLS estimates; they concluded that the high correlation between parental schooling and their offspring's education is due to unobserved abilities and family background rather than causal relationships. Oreopoulos, Page, and Stevens (2006) examined the causality in parents and their children by exploiting the variation in implementing compulsory schooling laws across states in the United States. They found that increasing parents' education reduces the probability of children repeating grades. Stella (2013) used the change in compulsory schooling reforms across nine European countries over the period 1920-56 as an IV to instrument parents' years of education; he found that the size of the estimated effect of parents' education on their offspring's education is larger. He also concluded that mothers' schooling is more important than fathers' education for the academic performance of their children.

\section{DATA AND MEASUREMENTS}

\subsection{Study Sample}

This study uses a cross-sectional, micro-level survey containing information on approximately 6,000 students enrolled in grades 5-9 in single-sex primary schools in the West Bank and East Jerusalem. The survey data were collected from May to September 2013 in the context of a cooperative research project funded by the German Research Foundation (DFG). A total of 100 schools were randomly selected based on their regional distribution (north, central, and south) and classified by education authority (60 governmental and 40 UNRWA). Then, from each school, 60 students were randomly selected and stratified by grade (12 students from each class). The students were asked to complete the standardized cognitive test and the health behavior questionnaire. Then, the school nurses collected their anthropometric measurements. The parents of the participants were asked to complete a survey directed to them. Another questionnaire was distributed to the school principals using the same items as those used in the Trends in International Mathematics and Science Study (TIMSS). 
This paper employs the following parts of the survey: (1) the standardized cognitive test; (2) student grades in different subjects obtained from the MoEHE records; and (3) the parental background questionnaire, which provides information about household income, parental education, age, and household structure. Due to the sample requirement, ${ }^{9}$ girls are overrepresented in this sample by approximately 67 percent. The contextual database on the locality level ${ }^{10}$ was collected from the Palestinian Central Bureau of Statistics (PCBS) and the World Bank Report, "Poverty in the Palestinian Territories, 2014," which includes information on the poverty level based on a household consumption survey from 2009. Finally, observations without parental education and cognitive score results were eliminated. Approximately 4,000 cases remain for the analyses across 98 schools (under the full specification).

\subsection{Parental Educational Attainment}

Parental educational level was measured with ten categories used by the PCBS from "illiterate" to "Ph.D." Out of 5,017 observations, 4,718 respondents (usually mothers) answered their level of education and provided information about their partner's education. Similar to other studies, I converted parents' educational levels into years of schooling. ${ }^{11}$ The summary statistics in table 2 show that fathers and mothers have a close level of education (the average schooling level is 10.77 years for mothers and 11.10 years for fathers).

The dataset that I used also provides information about both parents' years of birth, which enable me to determine whether parents' educational attainment was affected by exposure to the First Intifada during the identified age. Since fathers tend to be older than mothers, approximately 67 percent of mothers in my sample were exposed to the First Intifada, while 51 percent of fathers were exposed between the ages of 13 and 19 years, according to tables A.1 and A.2 in the appendix.

\footnotetext{
${ }^{9}$ To meet the selection criteria, single-sex schools should contain grades 5-9. Only 436 schools in the West Bank matched the sample requirement: 382 governmental schools (160 boys and 222 girls) and 54 UNRWA schools (20 boys and 34 girls). Private and gender-mixed schools were excluded.

10 The locality is the smallest administrative unit used by the PCBS.

11 I converted the educational attainment into years based on the number of grades in each level. For example, illiterate (0); can read and write (3 years); elementary (6 years); preparatory (9 years); secondary (12 years); diploma (14 years); bachelor (16 years); higher diploma (17 years); master (18 years); and Ph.D. (21 years). These classifications are very close to the ISCED-97 codes.
} 


\subsection{Outcome Variables}

\subsubsection{Cognitive Test Scores}

The primary outcome is the cognitive test scores. ${ }^{12}$ Students' cognitive ability was measured through exams distributed to all the students who participated in this survey; the test contains 181 items. These questions examine three aspects of a child's cognitive abilities: numerical, verbal, and figural. Each of the three groups consists of several subtests. Table A.3 in the appendix shows that the internal consistency (Cronbach's $\alpha$ ) is high for each subtest, for example 0.87 for the figure analogies test and 0.82 for the verbal classification test.

For the purpose of this study, the final results were obtained by computing the percentage of correctly answered items. Figure 2 shows that the distribution of the cognitive test results has a left-skewed distribution, with an arithmetic mean of 62 percent and a standard deviation of 17 percent. The cognitive result is profoundly affected by gender (females, in general, score better than males).

\section{Figure 2: Distribution of Cognitive Test Scores}

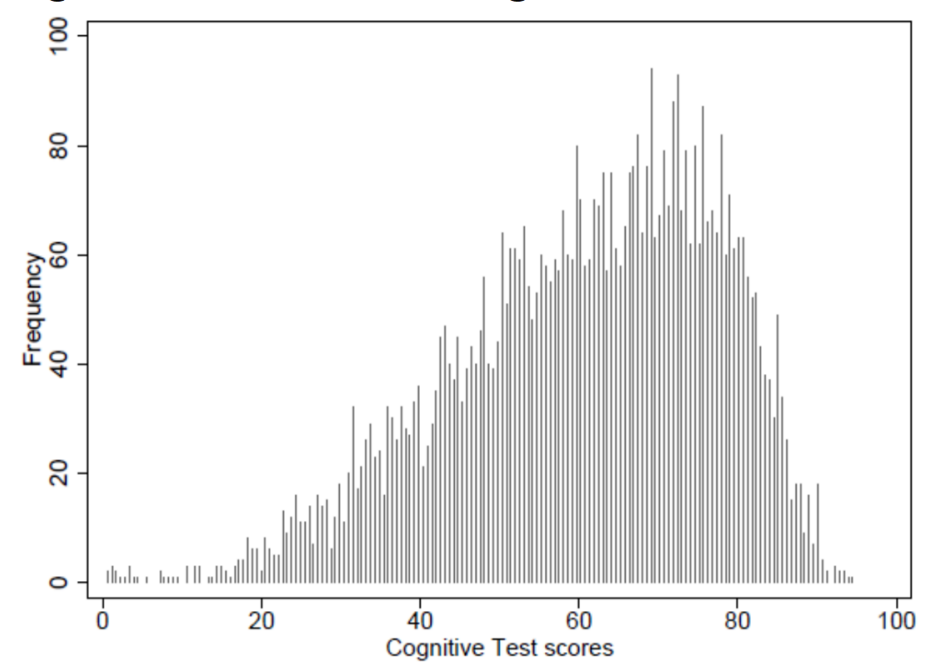

Source: Own calculations based on survey data.

\footnotetext{
${ }^{12}$ The test questions were selected and adapted from established tests of general ability: the Cognitive Ability Test (CAT) (Thorndike and Hagen 1971; Thorndike, Hagen, and Lorge 1971); Malta, a Hebrew version of the LorgeThorndike Test (Ortar and Shachor 1980); Standard Progressive Matrices (Raven 1983); and the Cattell and Cattell (1960a, 1960b) Culture Fair Intelligence Test.
} 


\subsubsection{School Achievements}

I use the school grade point average (GPA) in the academic year 2012/13 as a secondary outcome. To measure the educational performance, I compute students' GPA in the six major subjects taken by all students in all schools. ${ }^{13}$ These topics are religious education, Arabic, English, mathematics, science, and social science. All the courses are graded on a 100-point scale. The passing grade is 50 percent or more in all the subjects. In our sample, the school achievements have a mean of 68 percent and a standard deviation of 18 percent. ${ }^{14}$

\subsection{Control Variables}

In addition to the explanatory and outcome variables, I control for the following variables that could directly affect children's cognitive abilities and academic performance:

- Demographics: sex, age, and an indicator if student attended kindergarten.

- Household structure and socioeconomic status: the number of siblings, mother's and father's age, and household income per month. ${ }^{15}$

- School type: governmental or UNRWA schools. The school fixed effect is used since it captures a range of unobserved differences across schools that could influence student performance. It also covers other location-specific unobserved determinants of cognitive abilities (Brück, Di Maio, and Miaari 2019; Jürges and Schwarz 2015).

\footnotetext{
${ }^{13}$ Approximately 80 percent of the weekly lessons for the elementary grades are allocated to these six subjects (UNESCO 2011).

${ }^{14}$ All schools in the West Bank (public, UNRWA, and private) use the same national curriculum (MoEHE 2016b).

15 Education is not the only determinant of income in Palestine. Employment in Israel provides a wage premium over the local labor market. Individuals with higher levels of schooling are less likely to be employed in Israel. The dataset does not have an indicator of whether parents are working in Israel or not.
} 
- Contextual data: these variables are related to the locality of the students and consist of the population per locality in 2013 , the poverty rate, the percentage of this locality located in area $\mathrm{C},{ }^{16}$ and a dummy indicating whether this locality is affected by the separation wall. ${ }^{17}$

Table 1: Summary Statistics for Outcomes and Explanatory Variables

\begin{tabular}{lrrr}
\hline Variable & Observation & Mean & Std Dev. \\
Cognitive tests & 4,067 & 61.91 & 16.32 \\
School achievement (2012/13) & 4,065 & 67.85 & 18.43 \\
School achievement (2011/12) & 4,064 & 70.96 & 15.99 \\
Mother's years of education & 4,067 & 10.77 & 3.6 \\
Father's years of education & 4,023 & 11.1 & 3.8 \\
Mother with a college degree (0,1) & 4,067 & 0.19 & 0.4 \\
Father with a college degree (0,1) & 4,023 & 0.24 & 0.43 \\
Mother's years of Intifada (age 13-19) & 4,067 & 2.43 & 2.21 \\
Father's years of Intifada (age 13-19) & 4,067 & 1.86 & 2.22 \\
Male student & 4,067 & 0.3 & 0.46 \\
Student age (years) & 4,067 & 12.8 & 1.51 \\
Student went to kindergarten (KG) (0,1) & 4,067 & 0.11 & 0.31 \\
Number of siblings & 4,067 & 2.6 & 1.79 \\
Household net monthly income: & & & \\
<NIS 1500 & 4,067 & 0.36 & \\
NIS 1500-NIS 2499 & 4,067 & 0.33 & \\
NIS 2500-NIS 3999 & 4,067 & 0.17 & \\
NIS 4000-NIS 5000 & 4,067 & 0.08 & \\
>NIS 5000 & 4,067 & 0.06 & \\
Mother's age (years) & 4,067 & 39.57 & 6.58 \\
Father's age (years) & 4,067 & 44.8 & 7.09 \\
School authority (Gov. 1) & 4,067 & 0.59 & 0.49 \\
Population per locality (2013) & 4,067 & 28,563 & 50,826 \\
Separation wall (0,1) & 4,067 & 0.4 & 0.49 \\
Area C (proportion) & 4,067 & 0.3 & 0.3 \\
Poverty rate & 4,067 & 0.21 & 0.11 \\
\hline
\end{tabular}

\footnotetext{
${ }^{16}$ Area C: Areas in the West Bank still under full Israeli military and civil control based on the Oslo Accords of 1993, while the Palestinian Authority (PA) has civil and security control in area A. The PA has civil autonomy but no security control in area B (Vishwanath et al. 2014). Communities in area $\mathrm{C}$ are living in difficult life circumstances due to the lack of major services. For more details, see www.btselem.org/topic/area_c. ${ }^{17}$ The Israeli West Bank barrier or wall is a separation barrier built by the Israeli government in the West Bank along the 1949 armistice line known as the "Green Line" (B'Tselem 2012). The barrier divides Palestinian communities, encircles some, and isolates others from their surroundings while separating East Jerusalem from the rest of the West Bank (UNSCO 2014).
} 


\section{EMPIRICAL MODEL AND IDENTIFICATION STRATEGY}

To estimate the effect of parents' education on their offspring, I use the following model:

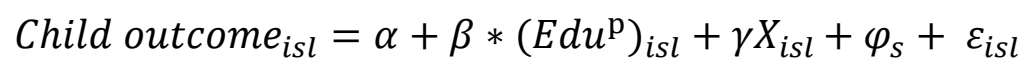

where unit of observation $i$ represents a child enrolled in school $s$ during the academic year 2012/13 in locality $l$ in the West Bank. The dependent variable is the child's cognitive test score (primary outcome) or student's academic performance (secondary outcome). Parental educational attainment $\left(E d u^{p}\right)$ is the variable of interest. Following Chevalier (2004), this variable is estimated separately for mothers and fathers to eliminate assortative mating bias and is measured by years of schooling. $\left(\mathrm{X}_{i s l}\right)$ denotes a set of controls at the level of the individual, family, locality, and school type, as mentioned in section 4.4. I also include the school-level fixed effect $\left(\varphi_{s}\right)$ to control unobservable differences across schools that may influence child outcomes. Finally, $\left(\varepsilon_{i s l}\right)$ represents an idiosyncratic error term. I cluster the standard errors at the school level.

As discussed earlier, parents' education is potentially endogenous and might be related to unobservable attributes of their offspring, such as ability, that explain the differences in children's cognitive abilities or educational outcomes. Therefore, parental educational attainment is instrumented by parents' exposure to the First Intifada during their preparatory and high school ages (13-19 years), which produces variation in their schooling that is exogenous and unlikely to be related to children's cognitive abilities or educational outcomes. ${ }^{18}$ The first-stage regression is given by:

$$
\left(E d u^{\mathrm{p}}\right)_{i s l}=\pi+\vartheta D_{i s l}+\delta X_{i s l}+\tau_{s}+\mu_{i s l}
$$

The dependent variable is parental educational attainment for child $i$ in school $s$ in locality $l$. The term $\left(X_{i s l}\right)$ is defined in the same way as in equation $(1) .\left(\tau_{s}\right)$ stands for the school fixed effect,

\footnotetext{
${ }^{18}$ The employed instrument cannot have affected children directly because they were all born after the First Intifada. The oldest group of individuals observed is in grade 9, born five years after the First Intifada ended.
} 
and $(D)$ is the instrument and denotes the number of years for which the child's parents were exposed to the First Intifada (1988-93) between the ages of 13-19. Thus, in equation (2), parameter $\vartheta$ measures the effect of parental exposure to the First Intifada. Tables A.1 and A.2 in the appendix show the construction of the instrument based on the year of birth for the parental sample and determines which parents were aged between 13 and 19 during the First Intifada; the values of the variables range from 0-6 years of exposure. For example, table A.1 indicates that if a student's father was born in 1972, then he was exposed to the First Intifada for four years during our specified age range. Likewise, a father born in 1975 was exposed for six years. Finally, $\left(\mu_{i s l}\right)$ represents an idiosyncratic error term and, similar to equation (1), standard errors are clustered at the school level.

The main assumption of this identification is that exposure to the First Intifada at a certain age should affect child outcomes only through its effect on the parental years of schooling. Nevertheless, there are a number of potential identification threats. Exposure to violent conflict may have an adverse long-term impact on the accumulated wealth of families, often caused by decreasing returns to education as a result of a reduction in productivity due to the collapse of the quality of education under conflict (Santos 2014). ${ }^{19}$ Thus, those parents who experienced the First Intifada during schooling age might face a decrease in their income, and their situation will be different from parents who did not have such an experience. I investigate the impact of the First Intifada on household income based on the following specification:

$$
(\text { Household income })_{i s l}=\tau+\phi D_{i s l}+\zeta F_{i s l}+\partial_{l}+\mu_{i s l}
$$

where the outcome variable is the household income for student $i$ enrolled in school $s$ in locality $l$ and represents different levels of family income (intervals). ${ }^{20}(D)$ is the instrument employed and

\footnotetext{
${ }^{19}$ Some literature has stated that the labor force participation stayed below the long-term average during the first ten years after the conflict (Bircan, Brück, and Vothknecht 2017). In general, during the conflict period, disruption exerted a negative impact on all economic activities, and the process of reaching full recovery is long (Cerra and Saxena 2008). However, other researchers have suggested that conflict can cause severe damage to the economy and human capital in the short run, while most countries recuperate in the long run after wars are over. For instance, one can observe Japan and West Germany, where the postwar economic recovery was speedy (Brakman, Garretsen, and Schramm 2004; Davis and Weinstein 2002).

${ }^{20} \mathrm{I}$ run an ordered logit model, since the outcome represents five unequal intervals for household income measured in the new Israeli shekel currency: [1] <1500; [2] 1500-2499; [3] 2500-3999; [4] 4000-5000; and [5] >5000.
} 
takes the value 1 if the father was exposed to the First Intifada between the ages of 13-19 years and 0 otherwise. The term $(F)$ captures the father's characteristics (schooling, age, and age squared). $\partial_{1}$ is the locality fixed effect. ${ }^{21}$ The results are presented in table A.4 in the appendix and suggest that there is no significant impact on income from paternal exposure to the First Intifada at the identified age. However, in Palestinian territories, education is not only the main tool for increasing income, as employment in Israel provides a wage premium over the local labor market and individuals with higher levels of schooling are less likely to be employed in Israel (Daoud 2005). Furthermore, in all the estimations, I include the household income to capture any impact of family wealth on their offspring's outcomes. Finally, the Palestinian economy experienced some improvements after the First Palestinian Intifada. As a result, the Palestinian National Authority was established in 1994, which provided more working opportunities inside the Palestinian territories (MAS 2014).

In addition to the economic consequences of the First Palestinian Intifada, it may have affected the psychological well-being of families. The literature has shed light on the direct effects of violent conflict, such as depression (Do and Iyer 2012; Swee 2011), as well as behavioral problems and post-traumatic stress disorder in both children and adolescents in Palestine (Mataria et al. 2009; Thabet, Abed, and Vostanis 2002). However, there is less evidence about this effect on human capital in the long run or the possibility that these effects will spill over to the next generation and negatively affect its members' well-being and human capital development (Akresh 2016). Finally, another threat to the identification strategy is the possibility that parents whose educational attainments were affected by the First Intifada may live in an area suffering from several long-term adverse life circumstances. This problem is mitigated by the employed model capturing several locality-level contextual variables as well as a school fixed effect, which covers other location-specific, unobserved determinants of students' outcomes.

\footnotetext{
${ }^{21}$ I run this regression only for fathers, since the majority of mothers in the sample are not working.
} 


\section{RESULTS AND DISCUSSION}

\subsection{First-Stage Regression (Intifada and Parents' Education)}

Exposure to the First Intifada during adolescence (13-19 years) had different effects on paternal and maternal educational attainment. Columns 7 and 8 in panel A of table 3 show the negative and significant impact of the First Intifada on fathers' years of education. Fathers who were exposed to the First Palestinian Intifada acquired 0.13 fewer years of schooling than other fathers who were not exposed to the First Intifada during the identified age. Additionally, table 8 shows that exposed fathers were 3.2 percentage points less likely to attend university or college than those who were not exposed.

This result is expected and consistent with the contextual data obtained during the First Intifada. Figure 1 demonstrates a sharp decrease in the enrollment of male students in West Bank universities and colleges during that period. There was a 20-24 percent reduction in enrollment from 1986-87. This may be attributed to the closure of educational institutions and lost school days. Furthermore, that period was characterized by economic instability; many young males sought low-skilled jobs in Israeli markets, which provided better wages. Figure 3.a shows the decrease in male participation in the labor force in Palestine during and after the First Intifada, since many of those males went to work inside Israeli territory.

Panel B of table 3 shows that females who were exposed to the First Intifada during the identified age (13-19 years) acquired 0.12 years of schooling compared with other females who were not exposed to the First Intifada at this age. ${ }^{22}$ This result emerged after controlling for both maternal age and age of marriage, since the latter could negatively affect the completion of education. Figure 1 shows that the number of female students increased slightly after the third year of the Intifada (1991). There are four plausible explanations for this positive correlation. First, the increase may be due to a reaction to the Israeli army's decision to close all educational institutions for approximately two years. Second, it may be due to an increase in the number of higher education institutions, in particular, several branches of Al-Quds Open University in West

\footnotetext{
${ }^{22}$ Further, table 7 indicates that those mothers were 0.7 percent more likely to complete their college or university education than other mothers who were not exposed to the First Intifada during the identified age.
} 
Bank cities and the Gaza Strip. ${ }^{23}$ In general, the demand for higher education increased after 1981, since several higher educational institutions opened (Angrist 1995). Third, it may be due to a change in women's work preference to support themselves and their families. For example, Shemyakina (2015) indicated a shift in the labor market outcome by gender after exposure to the 1992-98 armed conflict in Tajikistan. Further, Fernández, Ibáñez, and Peña (2014) suggested that females who experienced violent shocks in rural Colombia decreased their leisure time and increased the time devoted to household chores and caring for children and other family members.

Two pieces of evidence support the third reason. First, according to figure 3.b, female participation in the labor force increased continuously after the First Intifada and the establishment of the Palestinian National Authority in 1993. Further evidence was provided in the PCBS (1996) Labor Force Survey in 1995, which showed that 46 percent of female jobs fall into the categories of professionals, technicians, associates, and clerks (according to the international standard classification of occupations ISCO-08), all of which require at least 12-13 years of education. The traditional value of women's education, especially formal schooling, has strengthened over time. Formal education was perceived as a means of securing white-collar jobs with a steady income and to enhance the social status in a predominantly peasant society.

Finally, the alternative education process is implemented more efficiently in girls' schools. Most of the boys at this age were engaged in the Intifada's violent activities, and it was less risky for females to meet in one place, like public schools or worship houses, to conduct educational sessions. $^{24}$

\footnotetext{
${ }^{23}$ Al-Quds Open University officially started accepting students in 1991. This university adopted an open and remote educational system, with less demanding criteria for admission, such as a lower minimum score on the General Secondary Certificate Exam (compared with 65 percent in other universities at that time). Unlike other universities, regular attendance is not compulsory. The education process depends on paperwork systems instead of lectures and exams. For more details, see http://www.qou.edu/

${ }^{24}$ Some sociological studies (Ricks 2006) have indicated that during the First Intifada, high-school-age girls (16-18 years) played a vital role in the nonviolent resistance to the Israeli measures. They also insisted on attending schools just to study because they were always waiting for another curfew to be called. Another study, by Velloso (1996), concluded that girls' education in Palestine improved during and after the First Intifada. They played an active part during the struggle rather than doing nothing. This study indicated that women's organizations started their work in Palestine during and after the First Intifada, running projects for female empowerment and capacity building.
} 
Concerning the validity of the instrument, table 3, panel A also reports the corresponding Fstatistic of the first stage for each specification that accounts for the clustering of standard errors at the school level and the school fixed effect (columns 7 and 8). The F-statistic is greater than 10 and passes the rule of thumb for a weak instrument (Bound, Jaeger, and Baker 1995) for the main specification (around 22), but it falls to around 7 after adding the school fixed effect. In panel B, the first-stage regression is positive and significantly different from zero; the F-statistic is around 25 , but it falls to 8.6 after adding the school fixed effect.

\subsection{OLS and IV Regression Results}

The primary outcome of this study is the cognitive test scores. In the next section, I will present the impact of parents' education on students' school achievements.

Table 3 presents the main results of the OLS and IV regressions. The first-stage and reducedform estimations are also presented in the same table. Panel A shows the effects of fathers' years of education on their children's cognitive abilities, while the effect of mothers' educational attainment is presented in panel B.

Columns with odd numbers represent the estimations with all the control variables in addition to the school type (governmental versus UNRWA schools). Columns with even numbers show the results after adding the school fixed effect to the model.

In panel A, the OLS estimate suggests that a one-year increase in a father's years of schooling is associated with a 0.837 percentage point increase in his child's cognitive test. This coefficient is significant taking into consideration the inclusion of the set of controls that were discussed in the previous section. After including the school fixed effect in the model (column 2), I continue to find that fathers' education is positively and significantly associated with their children's cognitive abilities, although the coefficient is slightly lower: 0.75 . 
Figure 3.a: Male Participation in the Labor Force

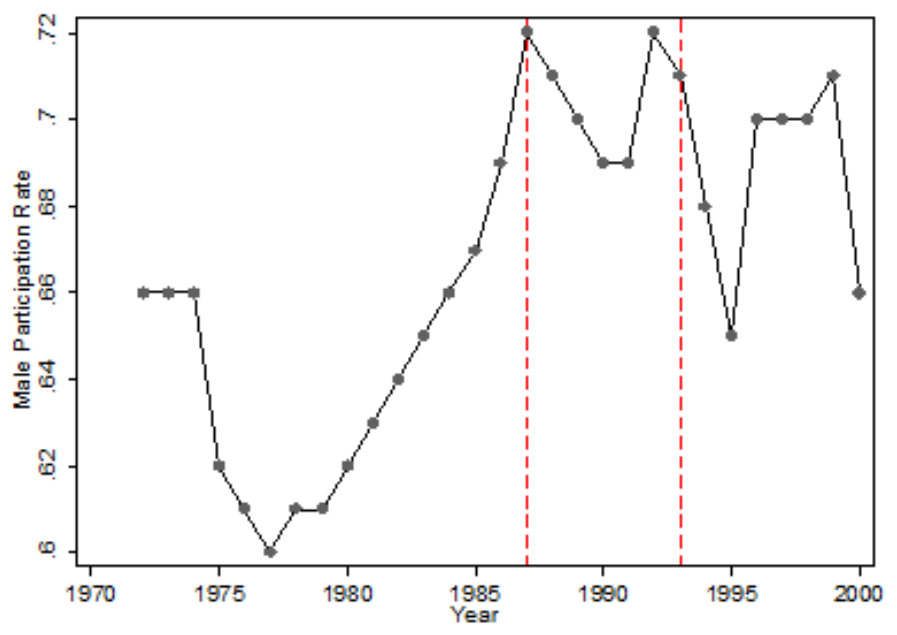

Figure 3.b: Female Participation in the Labor Force

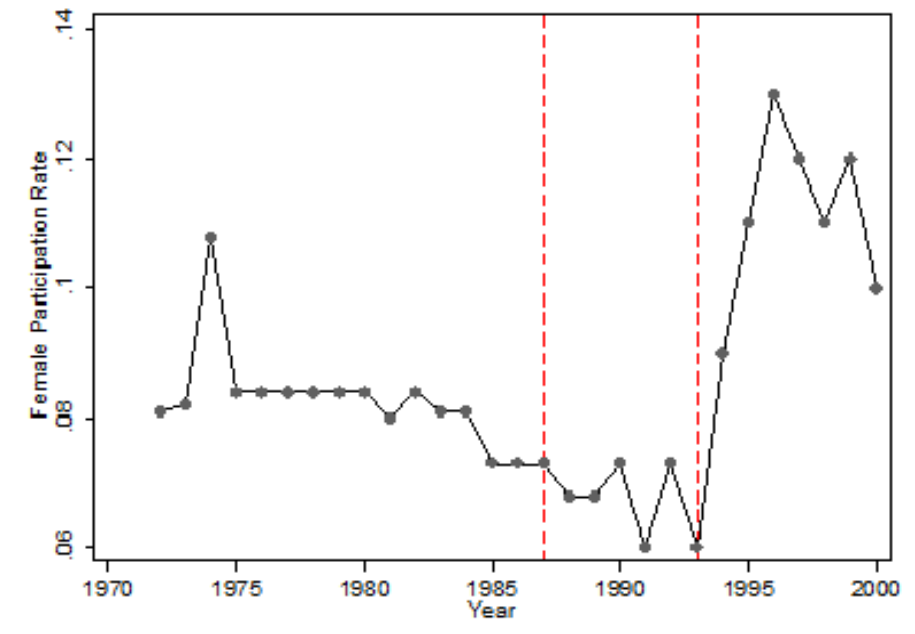

Source: Elkhafif and Daoud (2005)

Column 1 in panel B shows the effect of mothers' schooling on their children's cognitive outcome. The OLS estimate indicates that a one-year increase in a mother's education is associated with a 0.8 percentage point increase in her child's cognitive tests. The coefficient remains almost the same after adding the school fixed effect to the model. In general, the OLS estimates confirm a strong positive correlation between parents' years of schooling and their offspring's cognitive abilities, even when the school fixed effect, along with a large set of demographic and socioeconomic variables, is controlled for. In the following paragraphs, employing the IV strategy will allow me to explore whether this positive correlation is due to a 
causal relation or other omitted variables. Such omitted variables may include family characteristics or inherited ability transmitted to the children rather than education spillovers.

Columns 3 and 4, in panels A and B, respectively, present the two-stages least square (2SLS) results. The coefficients of both parents' education are imprecisely estimated and statistically insignificant. In panel A, column 3, the 2SLS estimate is smaller than the OLS estimate and falls from 0.464 to 0.298 percentage points after adding the school fixed effect. This result suggests that a child's cognitive ability is positively correlated with unobserved ability or family characteristics rather than human capital spillovers from father to child.

The 2SLS estimate for mothers indicates that a year of maternal education increases her child's cognitive ability tests by 1.131 percentage points. The IV estimate is slightly larger than the OLS but not significant due to the large standard error (1.003). Concerning the magnitudes, the effect of mothers' education becomes smaller when I introduce the school fixed effect into the estimation but is still larger than the OLS (0.722 percentage points versus 1.117 percentage points, respectively). The results suggest that there is evidence of a causal relationship for educational spillovers between mothers and their offspring despite the estimate's lack of precision.

\subsection{Change in Outcome by Student Gender}

In this section, I will try to explain the different roles that fathers and mothers play in the transmission of human capital by gender. Some of the literature states that same-sex intergenerational links are the strongest (Chevalier 2004), while other researchers have found, in contrast, a positive effect of mothers' education only on their sons (Black, Devereux, and Salvanes 2005). To conduct the analysis, I consider samples of male and female children separately. The results for sons and daughters are presented in table 4. Before discussing the 2SLS results, I will comment on the OLS results in panels A and B. The OLS estimates confirm that both parents' educational attainment has a stronger correlation with their daughters' cognitive outcome than with that of their sons ( 0.926 versus 0.659 , and 0.989 versus 0.335 percentage points, paternal and maternal, respectively). When conducting the analysis on girls, the IV coefficients for both parents' education are statistically significant and larger than those generated by the full sample ( 2.3 versus 0.404 for fathers and 2.023 versus 1.131 for mothers). 
Moreover, the IV estimates are greater than the OLS estimates. When examining the sample of sons, the IV estimation on paternal and maternal schooling yields an imprecise result, which is not statistically different from zero, with a high standard error and wrong sign. A potential explanation for the implausible result of parental education's effect on boys could be the sampling error rather than gender differences. Girls are more representative in my sample than boys (approximately 70 percent due to the sample requirement, as mentioned in section 4). The IV estimations demonstrate an educational spillover across generations. The size of the estimated effect is large: increasing paternal and maternal education by one year will raise their daughters' cognitive outcome by 2.3 percentage points and 2.03 percentage points, respectively. The smaller maternal effect may be due to the fact that better-educated mothers work more in paid employment and spend less time interacting with their daughters.

The results demonstrate an educational spillover across generations with respect to daughters only. Cultural specificity can explain this finding. In a mostly conservative society, such as that of Palestine, girls are more connected to their parents and spend most of their time either at school or at home, acquiring the majority of their experience by observing their parents. In contrast, boys are exposed to different experiences, having more choice when it comes to selecting their peers and interacting with their environment. ${ }^{25}$

\subsection{Outcome of School Achievements in 2012/13}

In this section, I will employ another vital educational outcome to investigate the human capital spillover. The students' school achievements during the academic year 2012/13 represent a long-term educational investment in children by their parents. A student's GPA is a good indicator, since it measures parents' investment in their child during the entire academic year rather than over a short period. These results are documented in the school administration records and measure the students' abilities in the main educational subjects. Moreover, the students' GPA during the year could reflect another indicator of the level and quality of nonschool "home" inputs into human capital production.

\footnotetext{
${ }^{25}$ For example, according to the PCBS (2014), males aged over 10 years tend to spend more time per day on leisure activities (sports participation and out-of-home exercises) than females (17 minutes per day versus 4 minutes, respectively). Meanwhile, the percentage of females engaged in performing domestic work in the West Bank is significantly larger than that for males ( 90.2 percent versus 43 percent).
} 
Thus far, the primary outcomes in the results suggest educational spillover effects of mothers' schooling on children's cognitive abilities, while the fathers' IV estimations lack precision with a large standard error. These findings are contrary to some pieces of literature that have found evidence that fathers' education is more important than that of mothers in influencing children's educational attainment (Ermisch and Pronzato 2010).

Table 5, panel A demonstrates that the IV estimates are higher than the OLS estimates of the effect of paternal educational attainment on children's school results. The IV estimates have the same sign as the OLS estimates and are statistically significant (10 percent). The OLS estimates suggest that increasing a father's education by one year increases the child's score by 1.19 percentage points. Moreover, the IV estimates show that one additional year of parental education significantly increases child school achievement by 1.5 percentage points. Introducing the school fixed effect into the model does not change the results.

The 2SLS model confirms a causal relation between paternal education and offspring's academic achievements. The findings show that the estimates obtained from the IV models are larger than their OLS counterparts. These results are consistent with the existing literature that instrumented parental educational attainment by introducing exogenous variation into family and contextual variables of interest, such as a change in compulsory school law, and found that IV estimates are larger than OLS estimates (Chevalier 2004; Oreopoulos et al. 2006; Stella 2013). That said, the finding could call into question the assumption of correlation between a child's education and other omitted variables, such as inherent genetic abilities or family input. 
The fact that the IV estimates are larger than the OLS estimates could be due to measurement error in self-reporting parental educational attainment (the endogenous variable). Another interpretation is the compiler effect, ${ }^{26}$ since the obtained results are consistent with the local average treatment effect (LATE) interpretation.

The First Intifada did not affect the entire population. The applied IV strategy captures the impact on only the subgroup of parents whose educational attainment was affected by exposure to the First Intifada at the identified age. Hence, the treatment effect of those parents whose schooling was upset by the First Intifada effect tends to be above the average marginal effect for the entire population, ${ }^{27}$ in particular those children whose parents completed their education or have less schooling, regardless of whether they were exposed to the First Intifada during the identified age range (always takers/never takers).

${ }^{26}$ The IV treatment divides observations into latent subgroups based on their compliance behavior:

"(1) Compliers: indicate to the subgroup of population who are pushed into treatment by the instrument. The instrument affects treatment status in the right direction. Those individuals do not take the treatment when they are not assigned. (2) Always takers: those individuals in this subgroup always take the treatment, regardless of whether they are assigned or not (i.e., the instrument does not affect treatment status). (3) Never-takers: those who would not take the treatment either way (i.e., the instrument does not affect treatment status). (4) Defiers: indicate to the subgroup of the population who always do the contradiction of the assignment. When assigned, they would not take the treatment, and when not assigned, they take it"; see Angrist and Pischke (2008) and Marbach et al. (2020).

${ }^{27}$ For example, Card (2001) pointed out that IV estimates based on changes in mandatory schooling laws will yield estimated returns to schooling above the average marginal return to schooling in the population and potentially above the corresponding OLS estimates, since the group of individuals captured by the LATE is most likely to be affected by the compulsory schooling law. 
Table 2: OLS and IV Estimates of the Effect of Parents' Years of Education on Cognitive Ability

\begin{tabular}{|c|c|c|c|c|c|c|c|c|}
\hline \multirow[b]{3}{*}{ Dependent variable: } & \multicolumn{2}{|c|}{ OLS } & \multicolumn{2}{|c|}{2 SLS } & \multicolumn{2}{|c|}{ Reduced form } & \multicolumn{2}{|c|}{ First stage } \\
\hline & $(1)$ & $(2)$ & (3) & (4) & $(5)$ & $(6)$ & $(7)$ & $(8)$ \\
\hline & \multicolumn{2}{|c|}{ Cognitive tests } & \multicolumn{2}{|c|}{ Cognitive tests } & \multicolumn{2}{|c|}{ Cognitive tests } & \multicolumn{2}{|c|}{ Parents' edu. } \\
\hline & & & Panel A & & & & & \\
\hline Father's years of education & $\begin{array}{c}0.837 * * * \\
(0.072)\end{array}$ & $\begin{array}{c}0.749 * * * \\
(0.064)\end{array}$ & $\begin{array}{c}0.464 \\
(0.745)\end{array}$ & $\begin{array}{c}0.298 \\
(0.887)\end{array}$ & & & & \\
\hline \multirow[t]{2}{*}{ Father's exposure to Intifada (age 13-19) } & & & & & -0.075 & -0.040 & $-0.163^{* * *}$ & $-0.133 * * *$ \\
\hline & & & & & $(0.123)$ & $(0.119)$ & $(0.029)$ & $(0.030)$ \\
\hline $\begin{array}{l}\text { First-stage F-statistic } \\
\text { Observations }\end{array}$ & 3,994 & 3,994 & 3,994 & 3,994 & 3,994 & 3,994 & $\begin{array}{l}21.73 \\
3,994\end{array}$ & $\begin{array}{c}6.72 \\
3.994\end{array}$ \\
\hline R-squared & 0.265 & 0.375 & 0.258 & 0.365 & 0.231 & 0.349 & 0.104 & 0.162 \\
\hline \multicolumn{9}{|c|}{ Panel B } \\
\hline Mother's years of education & $\begin{array}{c}0.790 * * * \\
(0.086)\end{array}$ & $\begin{array}{c}0.722 * * * \\
(0.078)\end{array}$ & $\begin{array}{c}1.131 \\
(1.003)\end{array}$ & $\begin{array}{c}1.117 \\
(1.138)\end{array}$ & & & & \\
\hline Mother's exposure to Intifada (age 13-19) & & & & & $\begin{array}{c}0.135 \\
(0.122)\end{array}$ & $\begin{array}{c}0.105 \\
(0.110)\end{array}$ & $\begin{array}{c}0.119 * * * \\
(0.025)\end{array}$ & $\begin{array}{c}0.094 * * * \\
(0.026)\end{array}$ \\
\hline First-stage F-statistic & & & & & & & 25.29 & 8.62 \\
\hline Observations & 4,067 & 4,067 & 4,067 & 4,067 & 4,067 & 4,067 & 4,067 & 4,067 \\
\hline R-squared & 0.254 & 0.366 & 0.249 & 0.360 & 0.228 & 0.347 & 0.134 & 0.212 \\
\hline Individual controls & YES & YES & YES & YES & YES & YES & YES & YES \\
\hline Family controls & YES & YES & YES & YES & YES & YES & YES & YES \\
\hline School type & YES & NO & YES & NO & YES & NO & YES & NO \\
\hline Contextual variables & YES & YES & YES & YES & YES & YES & YES & YES \\
\hline School FE & NO & YES & $\mathrm{NO}$ & YES & $\mathrm{NO}$ & YES & NO & YES \\
\hline
\end{tabular}

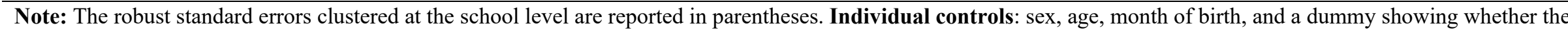
student attended kindergarten (KG). Family controls: number of siblings, household income, and father's and mother's age. School type: UNRWA or governmental.

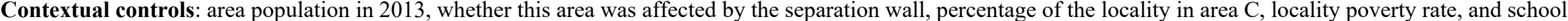
fixed effect. $* * * \mathrm{p}<0.01, * * \mathrm{p}<0.05$, and $* \mathrm{p}<0.1$. 
In panel B, I continue to find that a mother's education is positively and significantly associated with her child's scores. Increasing maternal schooling by one year increases the child's GPA by 1 percentage point. However, when the coefficient is instrumented, the 2SLS becomes lower than the OLS, with insignificant statistical power. Due to the lack of precision of the maternal IV estimates, and since the IV estimates are smaller than the OLS estimates, the results are not conclusive regarding the effect of maternal schooling on a child's school achievements. This may be due to possible correlation with other unobserved variables, such as ability or family background and characteristics, rather than a causal relationship.

The overall results in table 5 provide some evidence that fathers' education has a larger effect than that of mothers. As indicated by Ermisch and Pronzato (2010), the explanation for this result could be that better-educated mothers work more in paid employment and spend less time interacting with their offspring.

Table 6, panel A presents the OLS and IV estimates by gender differences. As I found with the main outcome variable, the IV father-all and father-daughter estimates are statistically significant, greater than the OLS estimates, and confirm the causality in the transmission of human capital. Despite the strong OLS relationship, in panel B, I find little causal relationship between maternal education and a child's school achievements. The only exception is mother-daughter relations; the IV estimate is still larger than the OLS estimate and provides some evidence of human capital spillover.

The overall IV findings are in the vicinity of the OLS estimations. Both cognitive test scores and students' school performances demonstrate the educational spillover in father-daughter and mother-daughter relations. While the father-son and mother-son coefficients are imprecisely estimated and lack significant power, these findings need further analysis to investigate whether the strong correlation between paternal schooling and sons' GPA is due to family characteristics or inherited ability rather than education spillovers. 
Table 3: OLS and IV Analysis: Effects of Parents' Educational Attainment on Cognitive Abilities by Gender

\begin{tabular}{|c|c|c|c|c|c|c|c|c|c|c|c|c|}
\hline \multirow[b]{2}{*}{$\begin{array}{l}\text { Dep. var: Cognitive } \\
\text { tests }\end{array}$} & \multicolumn{2}{|c|}{ All } & \multicolumn{2}{|c|}{ Girls } & \multicolumn{2}{|c|}{ Boys } & \multicolumn{2}{|c|}{ All } & \multicolumn{2}{|c|}{ Girls } & \multicolumn{2}{|c|}{ Boys } \\
\hline & (1) & $(2)$ & (3) & (4) & (5) & (6) & (7) & (8) & (9) & (10) & (11) & (12) \\
\hline & OLS & 2 SLS & OLS & 2 SLS & OLS & 2 SLS & OLS & 2 SLS & OLS & 2 SLS & OLS & 2 SLS \\
\hline \multicolumn{13}{|c|}{ Panel A } \\
\hline \multirow[t]{2}{*}{ Father's schooling } & $0.841 * * *$ & 0.404 & $0.926 * * *$ & $2.299 * *$ & $0.659 * * *$ & $-2.397^{*}$ & $0.757 * * *$ & 0.205 & $0.841^{* * *}$ & 1.989 & $0.573 * * *$ & -1.769 \\
\hline & $(0.073)$ & $(0.769)$ & $(0.079)$ & $(1.006)$ & $(0.135)$ & $(1.344)$ & $(0.065)$ & $(0.912)$ & $(0.076)$ & $(1.407)$ & $(0.115)$ & $(1.177)$ \\
\hline Observations & 3,994 & 3,994 & 2,803 & 2,803 & 1,191 & 1,191 & 3,994 & 3,994 & 2,804 & 2,804 & 1,191 & 1,191 \\
\hline First-stage F-statistic & & 21.73 & & 16.49 & & 9.08 & & 6.72 & & 7 & & 5.32 \\
\hline R-squared & 0.266 & 0.257 & 0.274 & 0.166 & 0.212 & & 0.377 & 0.363 & 0.354 & 0.284 & 0.366 & 0.168 \\
\hline \multicolumn{13}{|c|}{ Panel B } \\
\hline Mother's schooling & $0.790 * * *$ & 1.131 & $0.989 * * *$ & $2.023 * *$ & $0.335 * *$ & -1.190 & $0.722 * * *$ & 1.111 & $0.889 * * *$ & 1.660 & $0.335 * *$ & -0.595 \\
\hline & $(0.086)$ & $(1.003)$ & $(0.089)$ & $(0.878)$ & $(0.145)$ & $(4.150)$ & $(0.078)$ & $(1.138)$ & $(0.085)$ & $(1.107)$ & $(0.145)$ & $(4.180)$ \\
\hline Observations & 4,067 & 4,067 & 2,861 & 2,861 & 1,206 & 1,206 & 4,068 & 4,068 & 2,862 & 2,862 & 1,206 & 1,206 \\
\hline First-stage F-statistic & & 25.29 & & 19.88 & & 17.92 & & 8.62 & & 8.81 & & 5.76 \\
\hline R-squared & 0.254 & 0.249 & 0.266 & 0.212 & 0.358 & 0.126 & 0.366 & 0.361 & 0.344 & 0.317 & 0.358 & 0.332 \\
\hline Individual controls & YES & YES & YES & YES & YES & YES & YES & YES & YES & YES & YES & YES \\
\hline Family controls & YES & YES & YES & YES & YES & YES & YES & YES & YES & YES & YES & YES \\
\hline School type & YES & YES & YES & YES & YES & YES & NO & NO & NO & NO & NO & NO \\
\hline Contextual variables & YES & YES & YES & YES & YES & YES & YES & YES & YES & YES & YES & YES \\
\hline School FE & $\mathrm{NO}$ & $\mathrm{NO}$ & NO & $\mathrm{NO}$ & NO & NO & YES & YES & YES & YES & YES & YES \\
\hline
\end{tabular}

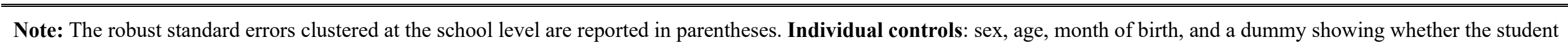

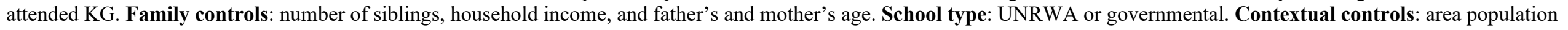

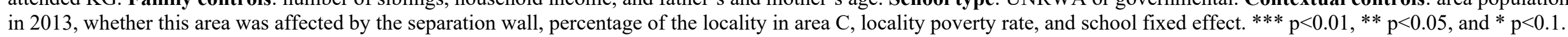


Table 4: OLS and IV Analysis: Effects of Parents' Years of Education on Children's School Achievement

\begin{tabular}{|c|c|c|c|c|c|c|c|c|}
\hline \multirow[b]{3}{*}{ Dependent variable: } & \multicolumn{2}{|c|}{ OLS } & \multicolumn{2}{|c|}{ 2SLS } & \multicolumn{2}{|c|}{ Reduced form } & \multicolumn{2}{|c|}{ First stage } \\
\hline & $(1)$ & $(2)$ & (3) & (4) & $(5)$ & $(6)$ & $(7)$ & $(8)$ \\
\hline & \multicolumn{2}{|c|}{ GPA2013 } & \multicolumn{2}{|c|}{ GPA2013 } & \multicolumn{2}{|c|}{ GPA2013 } & \multicolumn{2}{|c|}{ Parents' edu. } \\
\hline \multicolumn{9}{|c|}{ Panel A } \\
\hline Father's years of education & $\begin{array}{c}1.189 * * * \\
(0.084)\end{array}$ & $\begin{array}{c}1.186^{* * * *} \\
(0.085)\end{array}$ & $\begin{array}{l}1.524^{*} \\
(0.863)\end{array}$ & $\begin{array}{c}1.551 \\
(1.026)\end{array}$ & & & & \\
\hline Father's exposure to Intifada (age 13-19) & & & & & $\begin{array}{c}-0.242 * \\
(0.141)\end{array}$ & $\begin{array}{l}-0.204 \\
(0.142)\end{array}$ & $\begin{array}{c}-0.159 * * * \\
(0.029)\end{array}$ & $\begin{array}{c}-0.132 * * * \\
(0.031)\end{array}$ \\
\hline First-stage F-statistic & & & & & & & 21.67 & 6.69 \\
\hline Observations & 3,999 & 3,999 & 3,999 & 3,999 & 3,999 & 3,999 & 3,999 & 3,999 \\
\hline R-squared & 0.145 & 0.205 & 0.141 & 0.200 & 0.092 & 0.155 & 0.117 & 0.172 \\
\hline \multicolumn{9}{|c|}{ Panel B } \\
\hline Mother's years of education & $\begin{array}{c}1.236^{* * *} \\
(0.096)\end{array}$ & $\begin{array}{c}1.194 * * * \\
(0.096)\end{array}$ & $\begin{array}{c}0.869 \\
(1.035)\end{array}$ & $\begin{array}{c}0.928 \\
(1.225)\end{array}$ & & & & \\
\hline Mother's exposure to Intifada (age 13-19) & & & & & $\begin{array}{c}0.105 \\
(0.130)\end{array}$ & $\begin{array}{c}0.089 \\
(0.122)\end{array}$ & $\begin{array}{c}0.121 * * * \\
(0.025)\end{array}$ & $\begin{array}{c}0.096^{* * *} \\
(0.026)\end{array}$ \\
\hline First-stage F-statistic & & & & & & & 25.06 & 8.55 \\
\hline Observations & 4,073 & 4,073 & 4,073 & 4,073 & 4,073 & 4,073 & 4,073 & 4,073 \\
\hline R-squared & 0.142 & 0.200 & 0.138 & 0.198 & 0.092 & 0.158 & 0.133 & 0.211 \\
\hline Individual controls & YES & YES & YES & YES & YES & YES & YES & YES \\
\hline Family controls & YES & YES & YES & YES & YES & YES & YES & YES \\
\hline School type & YES & NO & YES & NO & YES & NO & YES & NO \\
\hline Contextual variables & YES & YES & YES & YES & YES & YES & YES & YES \\
\hline School FE & NO & YES & NO & YES & $\mathrm{NO}$ & YES & NO & YES \\
\hline
\end{tabular}

Note: The robust standard errors clustered at the school level are reported in parentheses. Individual controls: sex, age, month of birth, and a dummy indicating whether the student attended KG. Family controls: number of siblings, household income, and father's and mother's age. School type: UNRWA or governmental. Contextual controls: area population in 2013, whether this area was affected by the separation wall, percentage of the locality in area C, locality poverty rate, and school fixed effect. $* * * \mathrm{p}<0.01, * * \mathrm{p}<0.05$, and $* \mathrm{p}<0.1$. 
Table 5: OLS and IV Analysis: Effects of Parents' Educational Attainment on School Achievements by Gender

\begin{tabular}{|c|c|c|c|c|c|c|c|c|c|c|c|c|}
\hline \multirow{3}{*}{$\begin{array}{l}\text { Dep. var.: } \\
\text { GPA2013 }\end{array}$} & \multicolumn{2}{|c|}{ All } & \multicolumn{2}{|c|}{ Girls } & \multicolumn{2}{|c|}{ Boys } & \multicolumn{2}{|c|}{ All } & \multicolumn{2}{|c|}{ Girls } & \multicolumn{2}{|c|}{ Boys } \\
\hline & (1) & (2) & (3) & (4) & $(5)$ & (6) & (7) & (8) & (9) & (10) & (11) & (12) \\
\hline & $\underline{\mathrm{OLS}}$ & $\underline{2 \mathrm{SLS}}$ & $\underline{\mathrm{OLS}}$ & $\underline{2 \mathrm{SLS}}$ & $\underline{\mathrm{OLS}}$ & $\underline{2 \mathrm{SLS}}$ & $\underline{\mathrm{OLS}}$ & $\underline{\underline{2 S L S}}$ & $\underline{\mathrm{OLS}}$ & $\underline{2 \mathrm{SLS}}$ & $\underline{\mathrm{OLS}}$ & $\underline{2 \mathrm{SLS}}$ \\
\hline \multicolumn{13}{|c|}{ Panel A } \\
\hline Father's schooling & $\begin{array}{c}1.186^{* * *} \\
(0.083)\end{array}$ & $\begin{array}{l}1.524 * \\
(0.863)\end{array}$ & $\begin{array}{c}1.266^{* * *} \\
(0.104)\end{array}$ & $\begin{array}{c}2.024 \\
(1.346)\end{array}$ & $\begin{array}{c}1.055^{* * *} \\
(0.134)\end{array}$ & $\begin{array}{c}0.452 \\
(0.910)\end{array}$ & $\begin{array}{c}1.184 * * * \\
(0.085)\end{array}$ & $\begin{array}{c}1.551 \\
(1.026)\end{array}$ & $\begin{array}{c}1.252 * * * \\
(0.106)\end{array}$ & $\begin{array}{c}2.128 \\
(1.848)\end{array}$ & $\begin{array}{c}1.083^{* * *} \\
(0.132)\end{array}$ & $\begin{array}{c}0.722 \\
(0.960)\end{array}$ \\
\hline Observations & 3,999 & 3,999 & 2,804 & 2,804 & 1,195 & 1,195 & 3,999 & 3,999 & 2,804 & 2,804 & 1,195 & 1,195 \\
\hline $\begin{array}{l}\text { First-stage F- } \\
\text { statistic }\end{array}$ & & 25.06 & & 16.33 & & 9.18 & & 6.69 & & 6.69 & & 5.36 \\
\hline R-squared & 0.145 & 0.141 & 0.132 & 0.111 & 0.208 & 0.194 & 0.205 & 0.2 & 0.187 & 0.161 & 0.269 & 0.264 \\
\hline \multicolumn{13}{|c|}{ Panel B } \\
\hline Mother's schooling & $\begin{array}{c}1.240 * * * \\
(0.096)\end{array}$ & $\begin{array}{c}0.869 \\
(1.037)\end{array}$ & $\begin{array}{c}1.398 * * * \\
(0.113)\end{array}$ & $\begin{array}{c}1.786 \\
(1.124)\end{array}$ & $\begin{array}{c}0.876^{* * *} \\
(0.159)\end{array}$ & $\begin{array}{l}-2.693 \\
(2.951)\end{array}$ & $\begin{array}{c}1.197^{* * *} \\
(0.097)\end{array}$ & $\begin{array}{c}0.919 \\
(1.224)\end{array}$ & $\begin{array}{c}1.344^{* * *} \\
(0.113)\end{array}$ & $\begin{array}{c}2.088 \\
(1.430)\end{array}$ & $\begin{array}{c}0.876^{* * *} \\
(0.159)\end{array}$ & $\begin{array}{l}-2.418 \\
(3.072)\end{array}$ \\
\hline Observations & 4,073 & 4,073 & 2,863 & 2,863 & 1,210 & 1,210 & 4,073 & 4,073 & 2,863 & 2,863 & 1,210 & 1,210 \\
\hline $\begin{array}{l}\text { First-stage F- } \\
\text { statistic }\end{array}$ & & 25.06 & & 18.9 & & 7.5 & & 8.55 & & 8.64 & & 5.62 \\
\hline R-squared & 0.143 & 0.138 & 0.137 & 0.132 & 0.247 & & 0.201 & 0.199 & 0.19 & 0.174 & 0.247 & \\
\hline Individual controls & YES & YES & YES & YES & YES & YES & YES & YES & YES & YES & YES & YES \\
\hline Family controls & YES & YES & YES & YES & YES & YES & YES & YES & YES & YES & YES & YES \\
\hline School type & YES & YES & YES & YES & YES & YES & NO & NO & NO & NO & NO & NO \\
\hline Contextual var. & YES & YES & YES & YES & YES & YES & YES & YES & YES & YES & YES & YES \\
\hline School FE & NO & $\mathrm{NO}$ & NO & $\mathrm{NO}$ & NO & NO & YES & YES & YES & YES & YES & YES \\
\hline
\end{tabular}

Note: The robust standard errors clustered at the school level are reported in parentheses. Individual controls: sex, age, month of birth, and a dummy indicating whether the student went to KG. Family controls: number of siblings, household income, and father's and mother's age. School type: UNRWA or

governmental. Contextual controls: area population in 2013, whether this area was affected by the separation wall, percentage of the locality in area C, locality poverty rate, and school fixed effect. $* * * \mathrm{p}<0.01, * * \mathrm{p}<0.05$, and $* \mathrm{p}<0.1$. 


\section{ROBUSTNESS CHECKS}

In this section, I apply some robustness checks to verify the findings. First, I conduct the estimation on the sample with higher education cutoff points. I create a dummy variable for those parents with more than 12 years of schooling (university or college degree). One advantage of this check is that it eliminates the measurement error of self-reporting of parental education. Information about paternal and maternal schooling was obtained from the household questionnaire and classified into ten levels (from illiterate to Ph.D.) according to the PCBS scale. At some levels (for example preparatory), it is not clear whether parents have 7 or 9 years of education. The elementary stage is also unclear (grade 1 or 4). The OLS estimates in table 7 confirm a significant positive effect of parents with more than 12 years of education on their offspring's cognitive abilities, which is much larger in size than the OLS obtained for years of schooling. However, I continue to find that the IV for fathers with a college degree is smaller than the OLS estimate. In panel B, the IV estimate for mothers with a college degree is larger than the OLS estimate. Despite the estimate being insignificant due to the large standard error, it assumes a causal relation between highly educated mothers and their offspring, while the actual causal effect of paternal education on the child cognitive outcome appears to be weak. One exception is that when I run the regressions separately for parents and their daughters, I find that the IV estimates, especially for fathers, precisely confirm the causality in the intergenerational transmission of human capital and are larger than the OLS estimates.

Table 8 assumes a causal relationship between mothers with more than 12 years of education and their offspring's school achievements. Regarding the magnitudes, the IV estimate is greater than the OLS estimate (12 versus 9.051, respectively). The IV estimates give quite a close estimate of the OLS for the effect of fathers with more than 12 years of education on their offspring's school performance.

Another robustness check is implemented by considering the student's GPA as an outcome. By running the same regression on the previous academic year (2011/12), both the OLS and the IV estimates in table 9 yield similar results to those that were obtained in the main analysis. The 
2SLS for paternal schooling confirms an intergenerational educational spillover, while there is no such evidence for a causal relationship between maternal education and offspring's school performance.

\section{Table 6: OLS and IV Estimates of the Effect of a Parents' University Degree on Their Children's Cognitive Ability}

\begin{tabular}{|c|c|c|c|c|c|c|}
\hline \multirow{4}{*}{ Dependent variable: } & \multicolumn{2}{|c|}{ OLS } & \multicolumn{2}{|c|}{ 2SLS } & \multicolumn{2}{|c|}{ First stage } \\
\hline & (1) & (2) & (3) & (4) & $(5)$ & (6) \\
\hline & \multicolumn{2}{|c|}{ Cognitive tests } & \multicolumn{2}{|c|}{ Cognitive tests } & \multicolumn{2}{|c|}{ Parents' edu. } \\
\hline & \multicolumn{2}{|r|}{ Panel } & & & & \\
\hline Fathers with uni./college degree & $\begin{array}{c}5.058 * * * \\
(0.616)\end{array}$ & $\begin{array}{c}4.489 * * * \\
(0.527)\end{array}$ & $\begin{array}{c}2.239 \\
(3.610)\end{array}$ & $\begin{array}{c}1.295 \\
(3.873)\end{array}$ & & \\
\hline $\begin{array}{l}\text { Father's exposure to Intifada (age } \\
\text { 13-19) }\end{array}$ & & & & & $\begin{array}{c}-0.034 * * * \\
(0.003)\end{array}$ & $\begin{array}{c}-0.031 * * * \\
(0.003)\end{array}$ \\
\hline First-stage F-statistic & & & & & 24.82 & 7 \\
\hline Observations & 3,994 & 3,994 & 3,994 & 3,994 & 3,994 & 3,994 \\
\hline R-squared & 0.247 & 0.361 & 0.242 & 0.355 & 0.118 & 0.163 \\
\hline \multicolumn{7}{|c|}{ Panel B } \\
\hline Mothers with uni./college degree & $\begin{array}{c}4.918 * * * \\
(0.704)\end{array}$ & $\begin{array}{c}4.382 * * * \\
(0.678)\end{array}$ & $\begin{array}{c}15.684 \\
(14.623)\end{array}$ & $\begin{array}{c}14.035 \\
(15.491)\end{array}$ & & \\
\hline \multicolumn{3}{|c|}{ Mother's exposure to Intifada (age 13-19) } & & & $\begin{array}{c}0.009 * * * \\
(0.003)\end{array}$ & $\begin{array}{c}0.008 * * \\
(0.003)\end{array}$ \\
\hline First-stage F-statistic & & & & & 29.37 & 8.37 \\
\hline Observations & 4,067 & 4,067 & 4,067 & 4,067 & 4,067 & 4,067 \\
\hline R-squared & 0.24 & 0.355 & 0.182 & 0.312 & 0.153 & 0.201 \\
\hline Individual controls & YES & YES & YES & YES & YES & YES \\
\hline Family controls & YES & YES & YES & YES & YES & YES \\
\hline School type & YES & NO & YES & NO & YES & NO \\
\hline Contextual variables & YES & YES & YES & YES & YES & YES \\
\hline School FE & $\mathrm{NO}$ & YES & NO & YES & $\mathrm{NO}$ & YES \\
\hline
\end{tabular}

Note: The robust standard errors clustered at the school level are reported in parentheses. Individual controls: sex, age, month of birth, and a dummy indicating whether the student went to KG. Family controls: number of siblings, household income, and father's and mother's age. School type: UNRWA or governmental. Contextual controls: area population in 2013, whether this area was affected by the separation wall, percentage of the locality in area C, locality poverty rate, and school fixed effect. $* * * \mathrm{p}<0.01, * * \mathrm{p}<0.05$, and $* \mathrm{p}<0.1$. 


\section{Table 7: OLS and IV Estimates of the Effect of a Parents' University Degree on their}

Children's School Achievements

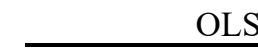

(1)

\section{OLS}

(2)
2SLS

(3)

(4)

First stage

(5) (6)

\begin{tabular}{|c|c|c|c|c|c|c|}
\hline \multirow{2}{*}{$\begin{array}{l}\text { Dependent variable: } \\
\text { Fathers with uni./college } \\
\text { degree }\end{array}$} & \multicolumn{2}{|c|}{ GPA2013 } & \multicolumn{2}{|c|}{ GPA2013 } & \multicolumn{2}{|c|}{ Parents' edu. } \\
\hline & $\begin{array}{c}7.626^{* * *} \\
(0.768)\end{array}$ & $\begin{array}{c}7.154 * * * \\
(0.772)\end{array}$ & $\begin{array}{l}7.277^{*} \\
(4.198)\end{array}$ & $\begin{array}{c}6.713 \\
(4.580)\end{array}$ & & \\
\hline & & & & & $-0.033 * * *$ & $-0.030 * * *$ \\
\hline $\begin{array}{l}\text { Father's exposure to } \\
\text { Intifada (age 13-19) }\end{array}$ & & & & & $(0.003)$ & $(0.003)$ \\
\hline First-stage F-statistic & & & & & 25.52 & 7.19 \\
\hline Observations & 3,999 & 3,999 & 3,999 & 3,999 & 3,999 & 3,999 \\
\hline R-squared & 0.12 & 0.179 & 0.12 & 0.179 & 0.134 & 0.175 \\
\hline $\begin{array}{l}\text { Mothers with uni./college } \\
\text { degree }\end{array}$ & $\begin{array}{c}9.051^{* * *} \\
(0.814)\end{array}$ & $\begin{array}{c}8.350^{* * *} \\
(0.826)\end{array}$ & $\begin{array}{c}12.004 \\
(14.275)\end{array}$ & $\begin{array}{c}11.542 \\
(15.231)\end{array}$ & & \\
\hline $\begin{array}{l}\text { Mother's exposure to } \\
\text { Intifada (age 13-19) }\end{array}$ & & & & & $\begin{array}{c}0.009 * * * \\
(0.003)\end{array}$ & $\begin{array}{c}0.008 * * * \\
(0.003)\end{array}$ \\
\hline First-stage F-statistic & & & & & 29.37 & 8.37 \\
\hline Observations & 4,073 & 4,073 & 4,073 & 4,073 & 4,073 & 4,073 \\
\hline R-squared & 0.124 & 0.184 & 0.121 & 0.18 & 0.152 & 0.201 \\
\hline Individual controls & YES & YES & YES & YES & YES & YES \\
\hline Family controls & YES & YES & YES & YES & YES & YES \\
\hline School type & YES & NO & YES & NO & YES & NO \\
\hline Contextual variables & YES & YES & YES & YES & YES & YES \\
\hline School FE & NO & YES & NO & YES & $\mathrm{NO}$ & YES \\
\hline
\end{tabular}

Note: The robust standard errors clustered at the school level are reported in parentheses. Individual controls: sex, age, month of birth, and a dummy indicating whether the student attended KG. Family controls: number of siblings, household income, and father's and mother's age. School type: UNRWA or governmental. Contextual controls: area population in 2013, whether this area was affected by the separation wall, percentage of the locality in area C, locality poverty rate, and school fixed effect. ${ }^{* *} \mathrm{p}<0.01,{ }^{* *} \mathrm{p}<0.05$, and $* \mathrm{p}<0.1$. 
Table 8: Robustness Checks, OLS, and IV Estimates of the Effect of Parents' Years of Education on School Achievements

\begin{tabular}{|c|c|c|c|c|c|c|c|c|}
\hline \multirow[t]{3}{*}{ Dep. var. } & \multicolumn{4}{|c|}{ Student GPA 2011/2012 } & \multicolumn{4}{|c|}{ Student GPA 2012/13 } \\
\hline & \multicolumn{2}{|c|}{ OLS } & \multicolumn{2}{|c|}{ 2SLS } & \multicolumn{2}{|c|}{ OLS } & \multicolumn{2}{|c|}{ 2SLS } \\
\hline & (1) & (2) & (3) & (4) & (5) & (6) & (7) & (8) \\
\hline \multicolumn{9}{|c|}{ Panel A } \\
\hline $\begin{array}{l}\text { Father's years of } \\
\text { education }\end{array}$ & $\begin{array}{c}1.107 * * * \\
(0.070)\end{array}$ & $\begin{array}{c}1.084 * * * \\
(0.069)\end{array}$ & $\begin{array}{l}1.758^{* *} \\
(0.717)\end{array}$ & $\begin{array}{l}1.711^{*} \\
(0.871)\end{array}$ & $\begin{array}{c}1.190 * * * \\
(0.084)\end{array}$ & $\begin{array}{c}1.188 * * * \\
(0.085)\end{array}$ & $\begin{array}{l}1.553^{*} \\
(0.865)\end{array}$ & $\begin{array}{c}1.593 \\
(1.032)\end{array}$ \\
\hline $\begin{array}{l}\text { First-stage F- } \\
\text { statistic }\end{array}$ & & & 22.89 & 7.08 & & & 22.81 & 7.06 \\
\hline Observations & 3,998 & 3,998 & 3,998 & 3,998 & 3,996 & 3,996 & 3,996 & 3,996 \\
\hline $\mathrm{R}$-squared & 0.193 & 0.243 & 0.172 & 0.224 & 0.145 & 0.205 & 0.140 & 0.200 \\
\hline \multicolumn{9}{|c|}{ Panel B } \\
\hline $\begin{array}{l}\text { Mother's years of } \\
\text { education }\end{array}$ & $\begin{array}{c}1.050^{* * *} \\
(0.089)\end{array}$ & $\begin{array}{c}0.992 * * * \\
(0.088)\end{array}$ & $\begin{array}{c}0.536 \\
(0.964)\end{array}$ & $\begin{array}{c}0.567 \\
(1.198)\end{array}$ & $\begin{array}{c}1.236^{* * *} \\
(0.096)\end{array}$ & $\begin{array}{c}1.194 * * * \\
(0.096)\end{array}$ & $\begin{array}{c}0.858 \\
(1.033)\end{array}$ & $\begin{array}{c}0.924 \\
(1.221)\end{array}$ \\
\hline $\begin{array}{l}\text { First-stage F- } \\
\text { statistic }\end{array}$ & & & 27.1 & 9.32 & & & 26.95 & 9.28 \\
\hline Observations & 4,072 & 4,072 & 4,072 & 4,072 & 4,070 & 4,070 & 4,070 & 4,070 \\
\hline R-squared & 0.179 & 0.227 & 0.167 & 0.220 & 0.142 & 0.201 & 0.138 & 0.199 \\
\hline $\begin{array}{l}\text { Individual } \\
\text { controls }\end{array}$ & YES & YES & YES & YES & YES & YES & YES & YES \\
\hline Family controls & YES & YES & YES & YES & YES & YES & YES & YES \\
\hline School type & YES & NO & YES & NO & YES & NO & YES & NO \\
\hline $\begin{array}{l}\text { Contextual } \\
\text { variables }\end{array}$ & YES & YES & YES & YES & YES & YES & YES & YES \\
\hline School FE & NO & YES & $\mathrm{NO}$ & YES & NO & YES & NO & YES \\
\hline
\end{tabular}

Note: The robust standard errors clustered at the school level are reported in parentheses. Individual controls: sex, age, month of birth, and a dummy indicating whether the student attended KG. Family controls: number of siblings, household income, and father's and mother's age. School type: UNRWA or governmental. Contextual controls: area population in 2013, whether this area was affected by the separation wall, percentage of the locality in area C, locality poverty rate, and school fixed effect. ${ }^{* * *} \mathrm{p}<0.01,{ }^{* *} \mathrm{p}<0.05$, and $* \mathrm{p}<0.1$.

The third robustness check is undertaken by controlling the school performance for the previous year (2011/12) when the cognitive test scores are the outcome variable. In table A.6 in the appendix, the IV estimates for paternal education yield an imprecise smaller coefficient than the OLS estimates, with the wrong sign. However, the OLS estimate for maternal education produces a smaller coefficient than the one derived from the model without cognitive scores $(0.294$ versus 0.79 , respectively), while the IV estimate is still larger than the OLS estimate. Overall, the 2SLS results for maternal education suggest some evidence for a causal relationship for intergenerational transmission of human capital. On the other hand, the paternal 2SLS estimates confirm that the positive correlation between maternal education and a child's cognitive test scores is due to the 
association with other unobserved factors, such as ability, family background, or inherent genetics rather human capital spillovers.

The last robustness check is executed by changing the specification of the instrument. The primary instrument is constructed by recognizing the parents' exposure to the first Intifada between 13 and 19 years of age. One concern is that those parents of college age (19-22) were additionally influenced by the Intifada, and along these lines they had a lower chance of being admitted to colleges during that period. Table A.7 in the appendix does not support an educational spillover after changing the instrument specification. The IV lacks precision and has a high standard error. Indeed, even the first stage is significant, and the F-statistic is greater than 10 before adding the school fixed effect. However, the IV estimates are consistently lower than the OLS estimates with the wrong sign.

\section{CONCLUSION}

In this study, I use cognitive test scores from approximately 4,000 students from grade 5 to grade 9 in the West Bank to investigate the intergenerational transmission of human capital. I identify the exogenous effect of parental education using exposure to the First Palestinian Intifada as the IV. The results suggest a partial causal relationship between fathers' schooling and that of their children, while there is some evidence of an educational spillover between mothers and their offspring. However, when focusing on girls' and boys' results separately, I find that both mothers' and fathers' education have quite a similar causal impact solely on their daughters' cognitive test scores. Employing the school achievements for the 2012/13 academic year as a secondary outcome indicates a significant educational spillover between fathers and their offspring. Furthermore, this outcome confirms the positive educational spillover between both parents and their daughters. Nevertheless, there remains much to explore about parents' roles in enhancing their children's cognitive abilities and how these abilities are correlated with parents' education.

The findings of this study are in line with other existing literature that has discussed the intergenerational transmission of human capital. Cognitive test results suggest that maternal 
education has a larger impact on children than paternal education. These results are also consistent with other studies that have shed light on the educational spillover across generations. Black, Devereux, and Salvanes (2005) attributed this stronger effect of maternal education to positive assortative mating. Another explanation is the fact that women with more education have fewer children and therefore more resources to invest in each child's education. They also suggested that educated mothers may reduce the cost (in terms of effort) of education for the child. Chevalier (2004) indicated that the stronger effect of maternal education could be explained by the role that an educated mother plays in her family, for example spending more time with her children, helping them with homework, reading to them, or taking them outside.

The overall findings are consistent with the idea that policies aimed at improving education will have a substantial impact on the second generation. Although some unobserved variables related to the Palestinian context may exist and girls are overrepresented in the sample, the sampling process captures all West Bank governorates, thus enhancing the policy implications of the study.

Long-term impacts should be considered when estimating the social returns to education. The findings of this paper indicate the importance of education intervention policies that would augment human capital spillover across generations. Furthermore, understanding the benefits of investment in human capital can lead to a reduction in the inequality of opportunity in the educational attainment of subsequent generations. Another indication of the results is the long-run effect of educational destruction during conflict. Losing school days can be translated into significant loss not only in life but also in the educational outcomes of the next generation. Thus, formulating policies that undergird educational institutions during conflict periods will have a remarkable accumulated positive impact on human capital. 


\section{REFERENCES}

Akresh, R. 2016. "Climate change, conflict, and children.” The Future of Children 26(1): 51-71.

Anger, S., and G. Heineck. 2010. "Do smart parents raise smart children? The intergenerational transmission of cognitive abilities." Journal of Population Economics 23(3): 1105-32.

Angrist, J. D. 1995. "The economic returns to schooling in the West Bank and Gaza Strip." The American Economic Review 85(5):1065-87.

Angrist J. D., and J. S. Pischke. 2008. Mostly harmless econometrics: An empiricist's companion. Princeton, NJ: Princeton University Press.

ARIJ (Applied Research Institute-Jerusalem). 2007. “40 years of Israeli occupation 1967-2007.” Technical report. Bethlehem and Palestine: Applied Research Institute-Jerusalem.

Assaf, S. 1997. "Educational disruption and recovery in Palestine." In S. Tawil (ed.), Final report and case studies of the Workshop on Educational Destruction and Reconstruction in Disrupted Societies. Geneva: UN Educational, Scientific, and Cultural Organization (UNESCO).

B'Tselem. 2012. "The long-term impact of Israel's separation barrier in the West Bank." Technical report. Jerusalem: B'Tselem: The Israeli Information Center for Human Rights in the Occupied Territories. Available at:

https://www.btselem.org/publications/summaries/201210_arrested_development

Barber, B. K. 1997. "Palestinian children and adolescents during and after the Intifada." PalestineIsrael Journal IV(1): 23-33.

Bauer, P. C., and R. T. Riphahn. 2013. "Institutional determinants of intergenerational education transmission-Comparing alternative mechanisms for natives and immigrants." Labour Economics 25: 110-22.

Becker, G. S., and N. Tomes. 1994. "Human capital and the rise and fall of families. Human capital: a theoretical and empirical analysis with special reference to education." In G. S. Becker (ed.), Human capital: A theoretical and empirical analysis with special reference to education, 3rd ed. Chicago: University of Chicago Press.

Behrman, J. R., and M. R. Rosenzweig. 2005. Does increasing women's schooling raise the schooling of the next generation? Reply." American Economic Review 95(5): 1745-51.

Benabou, R. 1994. "Human capital, inequality, and growth: A local perspective." European Economic Review 38(3-4): 817-26.

Bircan, Ç., T. Brück, and M. Vothknecht. 2017. "Violent conflict and inequality." Oxford Development Studies 45(2): 125-44. 
Björklund, A., M. Lindahl, and E. Plug. 2006. "The origins of intergenerational associations: Lessons from Swedish adoption data." The Quarterly Journal of Economics 121(3): 9991028 .

Black, S. E., P. J. Devereux, and K. G. Salvanes. 2005. "Why the apple doesn't fall far: Understanding intergenerational transmission of human capital." American Economic Review 95(1): 437-49.

Bound, J., D. A. Jaeger, and R. M. Baker. 1995. "Problems with instrumental variables estimation when the correlation between the instruments and the endogenous explanatory variable is weak." Journal of the American Statistical Association 90(430): 443-50.

Brakman, S., H. Garretsen, and M. Schramm. 2004. "The strategic bombing of German cities during World War II and its impact on city growth." Journal of Economic Geography 4(2): 201-18.

Brück, T., M. Di Maio, and S. H. Miaari. 2019. "Learning the hard way: The effect of violent conflict on student academic achievement." Journal of the European Economic Association 17(5): 1502-37.

B'Tselem. 2017. "Fatalities in the first Intifada." Website. Jerusalem: B'Tselem: The Israeli Information Center for Human Rights in the Occupied Territories. Available at: http://www.btselem.org/statistics/first_intifada_tables

Card, D. 2001. "Estimating the return to schooling: Progress on some persistent econometric problems." Econometrica 69(5): 1127-60.

Cattell, R. B., and A. K. S. Cattell. 1960a. Culture fair intelligence test, scale 2. Champaign, IL: Institute for Personality and Ability Testing.

Cattell, R.B., and A. K. S. Cattell. 1960b. Measuring intelligence with the culture fair tests. Champaign, IL: Institute for Personality and Ability Testing.

Cerra, V., and S. C. Saxena. 2008. "Growth dynamics: the myth of economic recovery." American Economic Review 98(1): 439-57.

Chevalier, A. 2004. "Parental education and child's education: A natural experiment." IZA Discussion Paper No. 1153. Bonn, Germany: Institute for the Study of Labor (IZA).

Currie, J. 2001. "Early childhood education programs.” Journal of Economic Perspectives 15(2): $213-38$.

Daoud, Y. 2005. "Gender gap in returns to schooling in Palestine." Economics of Education Review 24(6): 633-49. 
Davis, D. R., and D. E. Weinstein. 2002. "Bones, bombs, and break points: the geography of economic activity." American Economic Review 92(5): 1269-89.

Do, Q. T., and L. Iyer. 2012. "Mental health in the aftermath of conflict.” In M. R. Garfinkel and S. Skaperdas (eds.), The Oxford handbook of the economics of peace and conflict. Oxford: Oxford University Press.

Duncan, G. J., K, A, Magnuson, and J. Ludwig. 2004. “The endogeneity problem in developmental studies." Research in Human Development 1(1-2): 59-80.

Elkhafif, M. A., and Y. S. Daoud. 2005. "A model for the Palestinian labor markets and wage earnings." In the proceedings of the Economic Research Forum's 12 annual conference, ERF-Cairo, Egypt, December.

Ermisch, J., and C. Pronzato. 2010. "Causal effects of parents' education on children's education." ISER Working Paper No. 2010-16. Essex, England: Institute for Social and Economic Research (ISER), University of Essex.

Fernández, M., A. M. Ibáñez, and X. Peña. 2014. "Adjusting the labour supply to mitigate violent shocks: Evidence from rural Colombia.” Journal of Development Studies 50(8): 1135-55.

Ghanem, G. J. 2012. "First Palestinian Intifada: Does Political Affiliation or Imprisonment Moderate the Negative Psychological Effects for Adolescents Exposed to Violence?" Doctoral dissertation. Washington, DC: George Washington University.

Glick, P., and D. E. Sahn. 2009. "Cognitive skills among children in Senegal: Disentangling the roles of schooling and family background." Economics of Education Review 28(2): 17888.

Grantham-McGregor, S. M., S. P. Walker, S. M. Chang, and C. A. Powell. 1997. "Effects of early childhood supplementation with and without stimulation on later development in stunted Jamaican children." The American Journal of Clinical Nutrition 66(2): 247-53.

Heckman, J. J. 2006. "Skill formation and the economics of investing in disadvantaged children." Science 312(5782): 1900-2.

Heckman, J., R. Pinto, and P. Savelyev. 2013. "Understanding the mechanisms through which an influential early childhood program boosted adult outcomes." American Economic Review 103(6): 2052-86.

Jürges, H. 2013. “Collateral damage: The German food crisis, educational attainment and labor market outcomes of German post-war cohorts." Journal of Health Economics 32(1): 286-303. 
Jürges, H., and A. Schwarz. 2015. "Political conflict, child mental health, and cognitive development." Verein für Socialpolitik/German Economic Association annual conference, "Economic Development—Theory and Policy," Muenster.

Lee, S. Y. T., N. Roys, and A. Seshadri. 2015. “The causal effect of parents' education on children's earnings.” Technical report, Mimeo.

López-Ibor Jr., J. J., G. Christodoulou, M. Maj, N. Sartorius, and A. Okasha. (eds.). 2005. Disasters and mental health, vol. 4. Hoboken, NJ: John Wiley and Sons.

Mahshi, K., and K. Bush. 1989. "The Palestinian uprising and education for the future." Harvard Educational Review 59(4): 470-84.

MAS (Palastine Economic Policy Research Institute). 2014. "Labour market and employment policies in Palestine.” Technical report. Ramallah, Palestine: Palestine Economic Policy Research Institute.

Marbach, M., and D. Hangartner. 2020. "Profiling Compliers and Noncompliers for InstrumentalVariable Analysis." Political Analysis Jul(1): 10.

Mataria, A., R. Giacaman, A. Stefanini, N. Naidoo, P. Kowal, and S. Chatterji. 2009. "The quality of life of Palestinians living in chronic conflict: assessment and determinants." The European Journal of Health Economics 10(1): 93-101.

MoEHE (Ministry of Education and Higher Education). 2015. "Statistical educational annual book, 2014/2015." Technical report. Ramallah, Palestine: Ministry of Education and Higher Education.

_. 2016a. "Palestinian Universities Statistical Year Book." Technical reports, 1985-97. Ramallah, Palestine: Ministry of Education and Higher Education.

—. 2016b. "About the Ministry." Ministry of Education and Higher Education website. Accessed April 25. Available at: http://www.moehe.gov.ps/general-education/general-education/Education-System

MoFP (Ministry of Finance and Planning). 2016. "Citizen budget." Technical report. Ramallah, Palestine: Ministry of Finance and Planning. Available at: http://www.pmof.ps/documents/10192/654283/2016CitizensBudget.pdf -

Nasser, I., L. N. Berlin, and S. Wong. (eds.). 2011. Examining Education, Media, and Dialogue Under Occupation: The Case of Palestine and Israel, vol. 11. Bristol, UK: Multilingual Matters.

Oreopoulos, P., M. E. Page, and A. H. Stevens. 2006. "The intergenerational effects of compulsory schooling.” Journal of Labor Economics 24(4): 729-60. 
Ortar, G., and A. Shachor. 1980. "MILTA: A battery of tests for ages 9 through 18." Jerusalem: Ministry of Education and Culture (in Hebrew).

Paxson, C., and N. Schady. 2007. "Cognitive development among young children in Ecuador the roles of wealth, health, and parenting." Journal of Human Resources 42(1): 49-84.

PCBS (Palestinian Central Bureau of Statistics). 1996. "Labor Force Survey 1995, main results." Technical report. Ramallah, Palestine: Palestinian Central Bureau of Statistics.

- 2014. "Women and men in Palestine: Issues and statistics." Technical report. Ramallah, Palestine: Palestine Central Bureau of Statistics.

Plug, E. 2004. 'Estimating the effect of mother's schooling on children's schooling using a sample of adoptees." American Economic Review 94(1): 358-68.

Qouta, S., R. L. Punamäki, and E. E. Sarraj. 1995. "The relations between traumatic experiences, activity, and cognitive and emotional responses among Palestinian children." International Journal of Psychology 30(3): 289-304.

Raven, J. C. 1983. The standard progressive matrices, 1938-83. New York: Psychological Corporation.

Ricks, T. M. 2006. "In their own voices: Palestinian high school girls and their memories of the intifadas and nonviolent resistance to Israeli occupation, 1987 to 2004." NWSA Journal 18(3): 88-103.

Robinson, G. E. 1997. Building a Palestinian state: The incomplete revolution. Bloomington, IN: Indiana University Press.

Santos, R. 2014. "Post-conflict returns to education: The case of Timor Leste.” Unpublished Ph.D. thesis. Brighton, UK: Institute of Development Studies.

Shemyakina, O. 2015. "Exploring the impact of conflict exposure during formative years on labour market outcomes in Tajikistan." The Journal of Development Studies 51(4): 422-46.

Stella, L. 2013. "Intergenerational transmission of human capital in Europe: evidence from SHARE.” IZA Journal of European Labor Studies 2(1): 13.

Swee, E. L. 2009. "On war and schooling attainment: The case of Bosnia and Herzegovina." Households in Conflict Network Working Paper No. 57. Brighton, UK: Households in Conflict Network.

Tessler, M. 2009. A history of the Israeli-Palestinian conflict. Bloomington, IN: Indiana University Press. 
Thabet, A. A. M., Y. Abed, and P. Vostanis. 2002. "Emotional problems in Palestinian children living in a war zone: a cross-sectional study." The Lancet 359(9320): 1801-4.

Thorndike, R. L., E. P. Hagen, and I. Lorge. 1971. Cognitive abilities test: Kindergarten-grades 12/13. Multi-level ed., levels AH (grades 3-13). Primary batteries 1 u. 2 (grades $K-3$ ). Boston: Houghton Mifflin.

UNESCO. 2011. "World data on education, 7th edition 2010/11.” Technical report. Paris: United Nations Educational, Scientific and Cultural Organization (UNESCO). Available at: http://www.ibe.unesco.org/fileadmin/user_upload/Publications/WDE/2010/pdfversions/Palestine.pdf

1995. "Primary and secondary education in the West Bank and Gaza Strip: Overview of the system and need for the development of the Ministry of Education." Technical report. Paris, France: United Nations Educational, Scientific and Cultural Organization.

UNRWA. 2014. "Educational research briefs publication plan.” Technical report. Amman, Jordan: United Nations Relief and Works Agency for Palestine Refugees in the Near East (UNRWA). Available at:

https://www.unrwa.org/sites/default/files/research_and_development_unit_research_brief s_-_2014_english.pdf

UNSCO. 2014. "Report to the Ad Hoc Liaison Committee New York." Technical report, September 22. New York: Office of the United Nations Special Coordinator for the Middle East Peace Process. Available at: https://unsco.unmissions.org/sites/default/files/un_ahlc_report_sept_2014.pdf

Van Leeuwen, B., and P. Foldvari. 2008. "Human Capital and Economic Growth in Asia 18902000: A Time-series Analysis." Asian Economic Journal 22(3): 225-40.

Velloso, A. 1996. "Women, society and education in Palestine." International Review of Education 42(5): 524-30.

Vishwanath, T., B. Blankespoor, F. Calandra, N. Krishnan, M. Mahadevan, and M. Yoshida. 2014. "Seeing believes: Poverty in the Palestinian territories." Technical report. Washington, DC: World Bank Group. 


\section{APPENDIX}

Table A.1: Fathers' Exposure to the First Intifada (1988-93) during the Ages of 13-19 Years

\begin{tabular}{|c|c|c|c|c|c|c|c|}
\hline Father's YOB & Freq. & 1988 & 1989 & 1990 & 1991 & 1992 & 1993 \\
\hline Before 1950 & 70 & 38 & 39 & 40 & 41 & 42 & 43 \\
\hline 1951 & 15 & 37 & 38 & 39 & 40 & 41 & 42 \\
\hline 1952 & 13 & 36 & 37 & 38 & 39 & 40 & 41 \\
\hline 1953 & 17 & 35 & 36 & 37 & 38 & 39 & 40 \\
\hline 1954 & 38 & 34 & 35 & 36 & 37 & 38 & 39 \\
\hline 1955 & 35 & 33 & 34 & 35 & 36 & 37 & 38 \\
\hline 1956 & 43 & 32 & 33 & 34 & 35 & 36 & 37 \\
\hline 1957 & 46 & 31 & 32 & 33 & 34 & 35 & 36 \\
\hline 1958 & 72 & 30 & 31 & 32 & 33 & 34 & 35 \\
\hline 1959 & 64 & 29 & 30 & 31 & 32 & 33 & 34 \\
\hline 1960 & 110 & 28 & 29 & 30 & 31 & 32 & 33 \\
\hline 1961 & 94 & 27 & 28 & 29 & 30 & 31 & 32 \\
\hline 1962 & 151 & 26 & 27 & 28 & 29 & 30 & 31 \\
\hline 1963 & 162 & 25 & 26 & 27 & 28 & 29 & 30 \\
\hline 1964 & 160 & 24 & 25 & 26 & 27 & 28 & 29 \\
\hline 1965 & 189 & 23 & 24 & 25 & 26 & 27 & 28 \\
\hline 1966 & 189 & 22 & 23 & 24 & 25 & 26 & 27 \\
\hline 1967 & 227 & 21 & 22 & 23 & 24 & 25 & 26 \\
\hline 1968 & 238 & 20 & 21 & 22 & 23 & 24 & 25 \\
\hline 1969 & 243 & 19 & 20 & 21 & 22 & 23 & 24 \\
\hline 1970 & 272 & 18 & 19 & 20 & 21 & 22 & 23 \\
\hline 1971 & 251 & 17 & 18 & 19 & 20 & 21 & 22 \\
\hline 1972 & 234 & 16 & 17 & 18 & 19 & 20 & 21 \\
\hline 1973 & 245 & 15 & 16 & 17 & 18 & 19 & 20 \\
\hline 1974 & 250 & 14 & 15 & 16 & 17 & 18 & 19 \\
\hline 1975 & 192 & 13 & 14 & 15 & 16 & 17 & 18 \\
\hline 1976 & 150 & 12 & 13 & 14 & 15 & 16 & 17 \\
\hline 1977 & 103 & 11 & 12 & 13 & 14 & 15 & 16 \\
\hline 1978 & 77 & 10 & 11 & 12 & 13 & 14 & 15 \\
\hline 1979 & 68 & 9 & 10 & 11 & 12 & 13 & 14 \\
\hline 1980 & 26 & 8 & 9 & 10 & 11 & 12 & 13 \\
\hline 1981 & 22 & 7 & 8 & 9 & 10 & 11 & 12 \\
\hline 1982 & 8 & 6 & 7 & 8 & 9 & 10 & 11 \\
\hline 1983 & 6 & 5 & 6 & 7 & 8 & 9 & 10 \\
\hline 1984 & 2 & 4 & 5 & 6 & 7 & 8 & 9 \\
\hline Total & 4,082 & & & & & & \\
\hline
\end{tabular}

Note: Number of observations exposed to the First Intifada $\quad 2,085$ 
Table A.2: Mothers' Exposure to the First Intifada (1988-93) during the Ages of 13-19 Years

\begin{tabular}{|c|c|c|c|c|c|c|c|}
\hline Mother's YOB & Freq. & 1988 & 1989 & 1990 & 1991 & 1992 & 1993 \\
\hline 1950 & 8 & 38 & 39 & 40 & 41 & 42 & 43 \\
\hline 1952 & 1 & 36 & 37 & 38 & 39 & 40 & 41 \\
\hline 1953 & 4 & 35 & 36 & 37 & 38 & 39 & 40 \\
\hline 1954 & 3 & 34 & 35 & 36 & 37 & 38 & 39 \\
\hline 1955 & 4 & 33 & 34 & 35 & 36 & 37 & 38 \\
\hline 1956 & 12 & 32 & 33 & 34 & 35 & 36 & 37 \\
\hline 1957 & 11 & 31 & 32 & 33 & 34 & 35 & 36 \\
\hline 1958 & 18 & 30 & 31 & 32 & 33 & 34 & 35 \\
\hline 1959 & 30 & 29 & 30 & 31 & 32 & 33 & 34 \\
\hline 1960 & 42 & 28 & 29 & 30 & 31 & 32 & 33 \\
\hline 1961 & 47 & 27 & 28 & 29 & 30 & 31 & 32 \\
\hline 1962 & 81 & 26 & 27 & 28 & 29 & 30 & 31 \\
\hline 1963 & 74 & 25 & 26 & 27 & 28 & 29 & 30 \\
\hline 1964 & 92 & 24 & 25 & 26 & 27 & 28 & 29 \\
\hline 1965 & 102 & 23 & 24 & 25 & 26 & 27 & 28 \\
\hline 1966 & 120 & 22 & 23 & 24 & 25 & 26 & 27 \\
\hline 1967 & 134 & 21 & 22 & 23 & 24 & 25 & 26 \\
\hline 1968 & 160 & 20 & 21 & 22 & 23 & 24 & 25 \\
\hline 1969 & 169 & 19 & 20 & 21 & 22 & 23 & 24 \\
\hline 1970 & 160 & 18 & 19 & 20 & 21 & 22 & 23 \\
\hline 1971 & 213 & 17 & 18 & 19 & 20 & 21 & 22 \\
\hline 1972 & 222 & 16 & 17 & 18 & 19 & 20 & 21 \\
\hline 1973 & 217 & 15 & 16 & 17 & 18 & 19 & 20 \\
\hline 1974 & 243 & 14 & 15 & 16 & 17 & 18 & 19 \\
\hline 1975 & 270 & 13 & 14 & 15 & 16 & 17 & 18 \\
\hline 1976 & 277 & 12 & 13 & 14 & 15 & 16 & 17 \\
\hline 1977 & 283 & 11 & 12 & 13 & 14 & 15 & 16 \\
\hline 1978 & 256 & 10 & 11 & 12 & 13 & 14 & 15 \\
\hline 1979 & 252 & 9 & 10 & 11 & 12 & 13 & 14 \\
\hline 1980 & 211 & 8 & 9 & 10 & 11 & 12 & 13 \\
\hline 1981 & 152 & 7 & 8 & 9 & 10 & 11 & 12 \\
\hline 1982 & 133 & 6 & 7 & 8 & 9 & 10 & 11 \\
\hline 1983 & 86 & 5 & 6 & 7 & 8 & 9 & 10 \\
\hline 1984 & 38 & 4 & 5 & 6 & 7 & 8 & 9 \\
\hline Total & 4,125 & & & & & & \\
\hline
\end{tabular}

Note: Number of observations exposed to the First Intifada 
Table A.3: Subtests of the Cognitive Test

\begin{tabular}{|c|c|c|c|}
\hline $\begin{array}{l}\text { Subtest no. } \\
\text { (1) }\end{array}$ & Subtest name & $\begin{array}{l}\text { No. of } \\
\text { items }\end{array}$ & $\begin{array}{c}\text { Cronbach's } \\
\alpha\end{array}$ \\
\hline \multicolumn{4}{|c|}{ Verbal tests } \\
\hline 1 & Verbal classification & 17 & 0.82 \\
\hline 3 & Verbal analogies & 18 & 0.76 \\
\hline 6 & Vocabulary & 30 & 0.73 \\
\hline 9 & Verbal oddities & 13 & 0.74 \\
\hline 12 & Sentence completion & 16 & 0.77 \\
\hline \multicolumn{4}{|c|}{ Numerical tests } \\
\hline 7 & Number series & 12 & 0.79 \\
\hline 11 & $\begin{array}{l}\text { Word arithmetic } \\
\text { problems }\end{array}$ & 13 & 0.78 \\
\hline \multicolumn{4}{|c|}{ Figural tests } \\
\hline 2 & Figure classification & 15 & 0.71 \\
\hline 4 & Figure analogies & 15 & 0.87 \\
\hline 5 & Matrices & 8 & 0.8 \\
\hline 8 & Figure series & 10 & 0.76 \\
\hline 10 & Figural oddities & 14 & 0.55 \\
\hline
\end{tabular}

Note: (1) Subtest order in the test

Table A.4: Effect of Exposure to the First Intifada on Household Income

\begin{tabular}{llcrr}
\hline \hline Outcome: Household income & $(1)$ & $(2)$ & $(3)$ & $(4)$ \\
\hline Exposure to Intifada (age 13-19) & 0.00926 & 0.0671 & 0.0724 & 0.0294 \\
& $(0.0550)$ & $(0.0566)$ & $(0.0597)$ & $(0.0615)$ \\
\hline Observations & 4,370 & 4,222 & 3,819 & 3,819 \\
Education & NO & YES & YES & YES \\
Age & NO & NO & YES & YES \\
Age squared & NO & NO & YES & YES \\
Locality fixed effect & NO & NO & NO & YES \\
\hline
\end{tabular}

Notes: The results are obtained by ordered logit regression. The outcome variable is household income in 2013, measured in the new Israeli shekel currency, and takes 5 intervals: [1] $<1500$; [2] 1500-2499; [3] 2500-3999; [4] 4000-5000; and [5] >5000. Fathers' exposure to the First Intifada is a dummy variable that takes the value 1 if the father was exposed to the First Intifada at the age of 13-19 years and 0 otherwise. The standard errors are in parentheses and clustered at the locality level. ${ }^{* * *} \mathrm{p}<0.01$, $* * \mathrm{p}<0.05, *$ and $\mathrm{p}<0$. 
Table A.5: OLS: The Effect of All the Variables on Cognitive Tests and School Performance

\begin{tabular}{|c|c|c|c|c|}
\hline \multirow{3}{*}{$\begin{array}{l}\text { Dep. var.: } \\
\text { Father's years of education }\end{array}$} & (1) & (2) & (3) & (4) \\
\hline & \multicolumn{2}{|c|}{ Cognitive tests } & \multicolumn{2}{|c|}{ GPA 2013} \\
\hline & $0.637 * * *$ & $0.584 * * *$ & $0.841 * * *$ & $0.871 * * *$ \\
\hline & $(0.069)$ & $(0.066)$ & $(0.084)$ & $(0.083)$ \\
\hline \multirow[t]{2}{*}{ Mother's years of education } & $0.519 * * *$ & $0.490 * * *$ & $0.852 * * *$ & $0.836 * * *$ \\
\hline & $(0.074)$ & $(0.072)$ & $(0.090)$ & $(0.091)$ \\
\hline \multirow[t]{2}{*}{ Male student } & $-7.822 * * *$ & -4.531 & $-3.055 * * *$ & $-6.841^{*}$ \\
\hline & $(0.500)$ & $(2.990)$ & $(0.603)$ & $(3.779)$ \\
\hline \multirow[t]{2}{*}{ Student age (years) } & $3.431 * * *$ & $3.467 * * *$ & $-1.027 * * *$ & $-1.018 * * *$ \\
\hline & $(0.155)$ & $(0.146)$ & $(0.187)$ & $(0.184)$ \\
\hline \multirow[t]{2}{*}{ Student attended KG } & 0.06 & -0.07 & -1.422 & $-1.623^{*}$ \\
\hline & $(0.728)$ & $(0.694)$ & $(0.879)$ & $(0.877)$ \\
\hline \multirow[t]{2}{*}{ Number of siblings } & $-0.505 * * *$ & $-0.443 * * *$ & $-0.814 * * *$ & $-0.928 * * *$ \\
\hline & $(0.136)$ & $(0.131)$ & $(0.164)$ & $(0.165)$ \\
\hline \multirow[t]{2}{*}{ Household net monthly income } & $1.289 * * *$ & $1.351 * * *$ & $1.534 * * *$ & $1.795 * * *$ \\
\hline & $(0.209)$ & $(0.204)$ & $(0.253)$ & $(0.257)$ \\
\hline \multirow[t]{2}{*}{ Population per locality (2013) } & 0 & $-0.000 *$ & $-0.000^{*}$ & 0 \\
\hline & 0.000 & 0.000 & 0.000 & 0.000 \\
\hline \multirow[t]{2}{*}{ Locality affected by the separation wall $(0,1)$} & $0.871^{*}$ & $-5.066^{*}$ & -0.929 & $-9.539 * *$ \\
\hline & $(0.509)$ & $(2.975)$ & $(0.613)$ & $(3.760)$ \\
\hline \multirow[t]{2}{*}{ Area C (proportion) } & $-4.811 * * *$ & 0.561 & -1.5 & -5.381 \\
\hline & $(0.878)$ & $(3.535)$ & $(1.058)$ & $(4.468)$ \\
\hline \multirow[t]{2}{*}{ School authority (gov. 1) } & $-4.695 * * *$ & & $-3.540 * * *$ & $-4.695 * * *$ \\
\hline & $(0.468)$ & & $(0.565)$ & $(0.468)$ \\
\hline Observations & 3,898 & 3,899 & 3,904 & 3,904 \\
\hline R-squared & 0.275 & 0.384 & 0.162 & 0.221 \\
\hline School FE & NO & YES & $\mathrm{NO}$ & YES \\
\hline
\end{tabular}

Notes: The robust standard errors clustered at the school level are reported in parentheses. ${ }^{* * *} \mathrm{p}<0.01, * *$ $\mathrm{p}<0.05$, and $* \mathrm{p}<0.1$. 
Table A.6: OLS and IV Estimates of the Effect of Parents' Years of Education on Cognitive Ability

\begin{tabular}{|c|c|c|c|c|}
\hline \multirow[b]{2}{*}{ Dep. var.: Cognitive tests } & \multicolumn{2}{|c|}{ OLS } & \multicolumn{2}{|c|}{ 2SLS } \\
\hline & $(1)$ & $(2)$ & $(3)$ & (4) \\
\hline \multicolumn{5}{|c|}{ Panel A } \\
\hline Father's years of education & $0.332 * * *$ & $0.267 * * *$ & -0.279 & -0.387 \\
\hline & $(0.070)$ & $(0.059)$ & $(0.716)$ & $(0.831)$ \\
\hline First-stage F-statistic & & & 37.54 & 11.48 \\
\hline Observations & 4,064 & 4,064 & 4,064 & 4,064 \\
\hline R-squared & 0.432 & 0.527 & 0.419 & 0.514 \\
\hline \multicolumn{5}{|c|}{ Panel B } \\
\hline Mother's years of education & $\begin{array}{r}0.294 * * * \\
(0.081)\end{array}$ & $\begin{array}{r}0.262 * * * \\
(0.069)\end{array}$ & $\begin{array}{r}0.870 \\
(0.891)\end{array}$ & $\begin{array}{r}0.853 \\
(1.044)\end{array}$ \\
\hline First-stage F-statistic & & & 65.48 & 10.44 \\
\hline Observations & 3,990 & 3,990 & 3,990 & 3,990 \\
\hline R-squared & 0.433 & 0.525 & 0.416 & 0.507 \\
\hline Individual controls & YES & YES & YES & YES \\
\hline Family controls & YES & YES & YES & YES \\
\hline School type & YES & NO & YES & NO \\
\hline Contextual variables & YES & YES & YES & YES \\
\hline GPA $2011 / 2012$ & YES & YES & YES & YES \\
\hline School FE & $\mathrm{NO}$ & YES & $\mathrm{NO}$ & YES \\
\hline
\end{tabular}

Notes: The robust standard errors clustered at the school level are reported in parentheses. Individual controls: sex, age, month of birth, and a dummy indicating whether the student attended KG. Family controls: number of siblings, household income, and father's and mother's age. School type: UNRWA or governmental. Contextual controls: area population in 2013, whether this area was affected by the separation wall, percentage of the locality in area $C$, and locality poverty rate. School achievement in 2011/2012 and school fixed effect. $* * * \mathrm{p}<0.01, * * \mathrm{p}<0.05$, and $* \mathrm{p}<0.1$. 
Table A.7: OLS and IV Estimates of the Effect of Parents with a University Degree on Their Children's Cognitive Abilities

\begin{tabular}{|c|c|c|c|c|c|c|}
\hline \multirow{4}{*}{ Dependent variable: } & \multicolumn{2}{|c|}{ OLS } & \multicolumn{2}{|c|}{ 2SLS } & \multicolumn{2}{|c|}{ First stage } \\
\hline & (1) & (2) & (3) & (4) & (5) & (6) \\
\hline & \multicolumn{2}{|c|}{ Cognitive tests } & \multicolumn{2}{|c|}{ Cognitive tests } & \multicolumn{2}{|c|}{ Parents' edu. } \\
\hline & \multicolumn{4}{|c|}{ Panel A } & & \\
\hline $\begin{array}{l}\text { Fathers with uni./college } \\
\text { degree }\end{array}$ & $\begin{array}{c}5.038 * * * \\
(0.626)\end{array}$ & $\begin{array}{l}4.515 * * * \\
(0.541)\end{array}$ & $\begin{array}{l}-10.999 \\
(13.916)\end{array}$ & $\begin{array}{l}-11.395 \\
(13.304)\end{array}$ & & \\
\hline $\begin{array}{l}\text { Father's exposure to } \\
\text { Intifada (age 19-22) }\end{array}$ & & & & & $\begin{array}{r}-0.045^{* * *} \\
(0.014)\end{array}$ & $\begin{array}{c}-0.043 * * * \\
(0.014)\end{array}$ \\
\hline First-stage F-statistic & & & & & 22.68 & 6.73 \\
\hline Observations & 3,994 & 3,994 & 3,994 & 3,994 & 3,994 & 3,994 \\
\hline R-squared & 0.248 & 0.363 & 0.088 & 0.214 & 0.108 & 0.156 \\
\hline & & & & & & \\
\hline $\begin{array}{l}\text { Mothers with uni./college } \\
\text { degree }\end{array}$ & $\begin{array}{c}4.918 * * * \\
(0.704)\end{array}$ & $\begin{array}{c}4.382 * * * \\
(0.678)\end{array}$ & $\begin{array}{c}-7.763 \\
(34.412)\end{array}$ & $\begin{array}{c}3.18 \\
(42.241)\end{array}$ & & \\
\hline $\begin{array}{l}\text { Mother's exposure to } \\
\text { Intifada (age 19-22) }\end{array}$ & & & & & $\begin{array}{r}0.015 \\
(0.013)\end{array}$ & $\begin{array}{c}0.011 \\
(0.014)\end{array}$ \\
\hline First-stage F-statistic & & & & & 30.11 & 8.6 \\
\hline Observations & 4,067 & 4,067 & 4,067 & 4,067 & 4,067 & 4,067 \\
\hline R-squared & 0.24 & 0.355 & 0.16 & 0.355 & 0.151 & 0.2 \\
\hline Individual controls & YES & YES & YES & YES & YES & YES \\
\hline Family controls & YES & YES & YES & YES & YES & YES \\
\hline School type & YES & NO & YES & NO & YES & NO \\
\hline Contextual variables & YES & YES & YES & YES & YES & YES \\
\hline School FE & $\mathrm{NO}$ & YES & $\mathrm{NO}$ & YES & $\mathrm{NO}$ & YES \\
\hline
\end{tabular}

Note: The robust standard errors clustered at the school level are reported in parentheses. Individual controls: sex, age, month of birth, and a dummy indicating whether the student attended KG. Family controls: number of siblings, household income, and father's and mother's age. School type: UNRWA or governmental. Contextual controls: area population in 2013, whether this area was affected by the separation wall, percentage of the locality in area C, locality poverty rate, and school fixed effect. $* * * \mathrm{p}<0.01,{ }^{* *} \mathrm{p}<0.05$, and $* \mathrm{p}<0.1$. 